mgr inż. Grzegorz KRAJEWSKI ${ }^{1}$

mgr inż. Wojciech WĘGRZYŃSKI ${ }^{1}$

Przyjęty/Accepted/Принята: 04.05.2014;

Zrecenzowany/Reviewed/Рецензирована: 06.11.2014;

Opublikowany/Published/Oпубликована: 31.12.2014;

\title{
WYKORZYSTANIE NARZĘDZI INŻYNIERII BEZPIECZEŃSTWA POŻAROWEGO W PROJEKTOWANIU I ODBIORZE SYSTEMÓW WENTYLACJI POŻAROWEJ GARAŻY ZAMKNIĘTYCH ${ }^{2}$
}

\author{
The use of Fire Safety Engineering in the Design and Commissioning \\ of Car Park Fire Ventilation Systems
}

\author{
Использование инжинерных решений пожарной безопасности \\ в проектировке и приёме систем противопожарной вентиляции \\ закрытых гаражей
}

\begin{abstract}
Abstrakt
Cel: Przedstawienie wiedzy związanej z zastosowaniem narzędzi inżynierii bezpieczeństwa pożarowego na etapie projektu i odbioru systemów wentylacji pożarowej, ze szczególnym uwzględnieniem elementów układu równań będącego podstawą metody CFD, modeli fizycznych wykorzystywanych w obliczeniach oraz warunków brzegowych związanych z pożarem.

Wprowadzenie: Projektowanie systemów wentylacji pożarowej garaży zamkniętych jest procesem skomplikowanym i wieloetapowym. Z uwagi na brak jednoznacznych krajowych wytycznych i jednoczesne postawienie w przepisach techniczno-budowlanych wymagań funkcjonalnych związanych z oceną skuteczności działania systemu proces ten jest trudny. Weryfikacja i ocena projektu wymaga szczegółowej wiedzy nie tylko z zakresu podstaw prawnych, ale również z zakresu wykorzystania nowoczesnych narzędzi inżynierskich takich jak metoda obliczeniowej mechaniki płynów (CFD) czy metod oceny skuteczności działania instalacji z wykorzystaniem gorącego dymu. Aby osoby mające styczność ze wspomnianymi analizami były w stanie samodzielnie ocenić podstawowe zagadnienia im przedstawiane, niezbędne jest zamknięcie podstawowej wiedzy z analizowanego zakresu w zwięzłe ramy, z jednoczesnym przedstawieniem bazy literaturowej, w której należy szukać odpowiedzi na trudniejsze pytania.

Metodologia: W pracy przedstawione zostały wyniki analizy literatury tematu, badań własnych autorów publikacji przeprowadzonych w ramach projektu rozwojowego NR 04000306 „Kontrola dymu i ciepła w garażach” oraz prac realizowanych w ramach tematów statutowych Instytutu Techniki Budowlanej oraz działalności bieżącej Zakładu Badań Ogniowych ITB.

Wnioski: Wykorzystanie nowoczesnych narzędzi inżynierii bezpieczeństwa pożarowego, jakimi są analizy z wykorzystaniem metody obliczeniowej mechaniki płynów (CFD) oraz metoda gorącego dymu jest dzisiaj powszechną procedurą towarzyszącą niemalże każdemu projektowi systemu wentylacji pożarowej garażu zamkniętego. Przedstawiane wyniki analiz są często trudne w interpretacji i niejednoznaczne. Osoby prowadzące weryfikację tych projektów, funkcjonariusze PSP odpowiadający za odbiór i inne podmioty biorące udział w procesie projektowania muszą mieć świadomość źródła pochodzenia przyjętych założeń i uproszczeń i być w stanie zweryfikować podstawy ich zastosowania. Dopiero takie, w pełni świadome, wykorzystanie narzędzi, którymi dysponujemy, daje pewność, że wyniki analiz są bliskie rzeczywistości, a wnioski z nich płynące poprawne.
\end{abstract}

Słowa kluczowe: wentylacja pożarowa, garaże zamknięte, wentylacja kanałowa, wentylacja strumieniowa Typ artykułu: artykuł przeglądowy

\section{Abstract}

Aim: Presentation of technical know-how associated with the application of Fire Safety Engineering (FSE) tools during the design and commissioning stage of ventilation systems in enclosed car parks. Specific focus is placed on the presentation of differential equations

\footnotetext{
${ }^{1}$ Instytut Techniki Budowlanej, ul. Filtrowa 1, 00-611 Warszawa / Building Research Institute, Warsaw, Poland / w.wegrzynski@itb.pl;

${ }^{2}$ Wkład merytoryczny w powstanie artykułu / Percentage contribution: W. Węgrzyński - 60\%, G. Krajewski - 40\%;
} 
which form the basis of the Computational Fluid Dynamics (CFD) technique, physical models used in computation and boundary conditions associated with fire incidents.

Introduction: The design of fire ventilation systems in enclosed car parks is a long, complicated and multi-staged process. The absence of clear national guidelines and simultaneous functional requirements, stipulated in technical construction regulations about effectiveness of the operating system, make the task more difficult. Evaluation of the design requires explicit knowledge, not only about standards and legal requirements, but also about the application of most up to date engineering tools, such as the computation method of fluid dynamics CFD or performance evaluation of installations with the application of heated smoke. Individuals tasked with previously mentioned responsibilities should be suitably equipped to address basic issues. It is essential to encapsulate fundamental knowledge of relevant elements within a succinct framework. Simultaneously, appropriate literature should be identified and made accessible to assist with a search for answers to more difficult questions.

Methodology: The article includes an analysis of relevant literature, studies conducted by authors under the auspices of a development grant nr. 04000306 "Smoke and heat control in car parks" as well as statutory tasks performed by the Building Research Institute (BRI) and finally ongoing activities of the Fire Research Department of BRI.

Conclusions: The use of modern FSE tools, such as CFD analysis or hot smoke performance evaluation are common procedures in current times. They are performed for almost every design of smoke and heat exhaust system in enclosed car parks. Interpretation of analysis results is often difficult and ambiguous. Individuals responsible for verification of the design, State Fire Service staff responsible for commissioning or others who participate in the project design have to understand the source of assumptions and simplifications which are made and be in a position to verify the basis for their application. Only such cognisant use of FSE tools will give confidence that evaluation results are close to reality and subsequent conclusions are correct.

Keywords: fire ventilation, enclosed car parks, smoke and heat exhaust systems, jet-fan ventilation Type of article: review article

\section{Аннотация}

Цель: Представление знаний, связанных с использованием инжинерных решений пожарной безопасности на этапе проекта и приёма систем противопожарной вентиляции, с особым учётом элементов системы уравнений, лежащей в основе метода $\mathrm{CFD}$, физических моделей используемых в вычислениях и граничных условий, связанных с пожаром.

Введение: Проектирование систем противопожарной вентиляции закрытых гаражей является сложным и многоступенчатым процессом. Из-за отсутствия чётких национальных руководящих принципов и одновременного наличия в правилах технических и строительных функциональных требований, связанных с оценкой эффективности работы системы, данный процесс является сложным. Верификация и оценка проекта требует специализированных знаний не только в сфере правовых основ, но также в сфере использования современных инжинерных решений, таких как вычислительная гидродинамика (CFD) или методы оценки эффективности работы установки с использованием горячего дыма. Чтобы люди, контактующие с упомянутыми исследованиями могли самостоятельно оценить основные представленные им вопросы, необходимо закрыть основную информацию из анализируемой сферы в определённых рамках, и одновременно представить литературную базу, в которой нужно искать ответы на сложные вопросы.

Методология: В работе представлены результаты анализа литературы на данную тему, собственных исследований авторов публикации, проводимых в рамках исследовательского проекта NR 04000306 „Контроль дыма и тепла в гаражах”, а также работ, проводимых в соответствии с установленным Институтом Строительной Техники (ITB) законом, а также текущей деятельности Отдела Огневых Испытаний Института Строительной Техники (ITB).

Выводы: Использование современных инжинерных решений в области пожарной безопасности, таких как анализ с использованием метода вычислительной гидродинамики (SFD), а также метод горячего дыма, является сегодня популярной процедурой, которая сопровождает почти каждый проект системы противопожарной вентиляции закрытого гаража. Представляемые результаты анализов часто очень сложные для интерпретации и неоднозначны. Люди, осуществляющие проверку этих процессов, сотрудники ГПС, ответственные за приём и другие субъекты, участвующие в процессе проектирования должны знать источник происхождения принятых предположений и упрощений и быть в состоянии проверить основы их применения. Только такое сознательное использование инструментов, которыми мы обладаем, дает уверенность, что результаты анализов ближе к реальности, а выводы, вытекающие из них - корректны.

Ключевые слова: противопожарная вентиляция, закрытые гаражи, канальная вентиляция, потоковая вентиляция Вид статьи: обзорная статья

\section{Wprowadzenie}

Problematyka projektowania i odbioru systemów wentylacji pożarowej garaży zamkniętych, choć na pierwszy rzut oka dobrze opisana w literaturze tematu i pozornie prosta do zastosowania w praktyce, nieustannie przysparza wielu problemów środowisku związanemu z bezpieczeństwem pożarowym. Odpowiedzi na wiele podstawowych pytań związanych ze wspomnianymi instalacjami miały dostarczyć realizowany w latach 2009-2012 projekt NR 04000306 pt. „Kontrola dymu i ciepła w garażach" [1], oraz inne prace naukowo-badawcze realizowane w Zakładzie Badań Ogniowych Instytutu Techni- ki Budowlanej [2],[3],[4],[5]. Wymagania stawiane systemom wentylacji pożarowej, w tym także systemom wentylacji pożarowej garaży zamkniętych, sformułowane w $\$ 270$ rozporządzenia MI w sprawie warunków technicznych, jakim powinny odpowiadać budynki i ich usytuowanie, mają charakter funkcjonalny [6],[7]. Oznacza to, że ustawodawca nie stawia wymagań formalnych związanych z parametrami wykorzystywanego systemu, lecz stawia cel jego zastosowania, a na projektancie spoczywa obowiązek zaprojektowania systemu, który umożliwi jego spełnienie, razem z przedstawieniem wiarygodnego dowodu potwierdzającego jego skuteczność. Wyma- 
gania stawiane systemom odnoszą się nie tylko do bezpieczeństwa mogących przebywać w przestrzeni garaży, ale także w stosunku do bezpieczeństwa ekip ratowniczo-gaśniczych. Dowód ich spełnienia może mieć charakter obliczeń analitycznych opartych na wiarygodnej metodologii przedstawionej w dokumencie normatywnym lub stanowić efekt wykorzystania nowoczesnych narzędzi inżynierii bezpieczeństwa pożarowego omawianych w niniejszej publikacji.

\section{Podzial systemów wentylacji pożarowej garaży zamkniętych}

Systemy wentylacji pożarowej można podzielić ze względu na cel ich działania oraz ze względu na rodzaj urządzeń wykorzystywanych do osiągnięcia celu. Systemy wentylacji pożarowej wykorzystywane w ochronie garaży dla samochodów osobowych, ze względu na cel, który z ich wykorzystaniem można zrealizować, dzieli się na [8]:

- wentylację oddymiającą (ang. SHEVS - Smoke and Heat Exhaust Ventilation) - system, którego zasadą działania jest usuwanie dymu z warstwy dymu zgromadzonej pod stropem i utrzymanie wolnej od dymu przestrzeni, w której mogą ewakuować się ludzie;

- systemy kontroli dymu i ciepła - system, którego zasadą działania jest utrzymanie dymu w wyznaczonym obszarze pomiędzy źródłem ognia a miejscem jego usuwania w taki sposób, aby zapewnić łatwy dostęp do źródła ognia dla ekip ratowniczych;

- systemy oczyszczania z dymu (ang. Smoke Clearence, dilute) - system, którego zadaniem jest usuwanie dymu i mieszanie dymu z napływającym powietrzem kompensacyjnym w celu zmniejszenia jego temperatury i toksyczności.
Ze względu na rodzaj wykorzystywanych urządzeń systemy dzieli się na systemy wentylacji przewodowej (kanałowej) będące zazwyczaj systemami wentylacji oddymiającej oraz strumieniowej pracujące zazwyczaj jako systemy kontroli dymu i ciepła. Obydwa rodzaje urządzeń mogą zostać wykorzystane jako systemy oczyszczania $\mathrm{z}$ dymu, przy czym w praktyce większość systemów tego typu to systemy wentylacji strumieniowej.

\section{Projektowanie systemów wentylacji pożarowej garaży zamkniętych}

Podstawowe zasady działania poszczególnych systemów przedstawiono na ryc. 2 . W opracowaniu nie będą poruszane zagadnienia związane z projektowaniem systemów wentylacji pożarowej, ich szczegółowe omówienie można odnaleźć w innych publikacjach autorów opracowania [9],[10],[11],[12] oraz w dokumentach normatywnych:

- $\quad$ BS 7346-7:2006 [13];

- NFPA 92:2012 [14];

- NFPA 204:2012 [15];

- NEN 6098:2010 [16];

- NBN S 21-208-2 [17];

- VDI 6019 Blatt 1 : 2006 [18];

- VDI 6019 Blatt 2 : 2009 [19];

- AS 4391 - 1999 [20];

- FSE3:2008 [21].

Podstawowe zasady projektowania systemów wentylacji pożarowej w garażach zamkniętych będą także przedmiotem opracowania Wytyczne projektowania, weryfikacji $i$ odbioru systemów wentylacji pożarowej $\mathrm{nr}$ 493/2015 opracowywanych w Zakładzie Badań Ogniowych ITB, których publikację przewidziano na I kwartał 2015 r. [22]

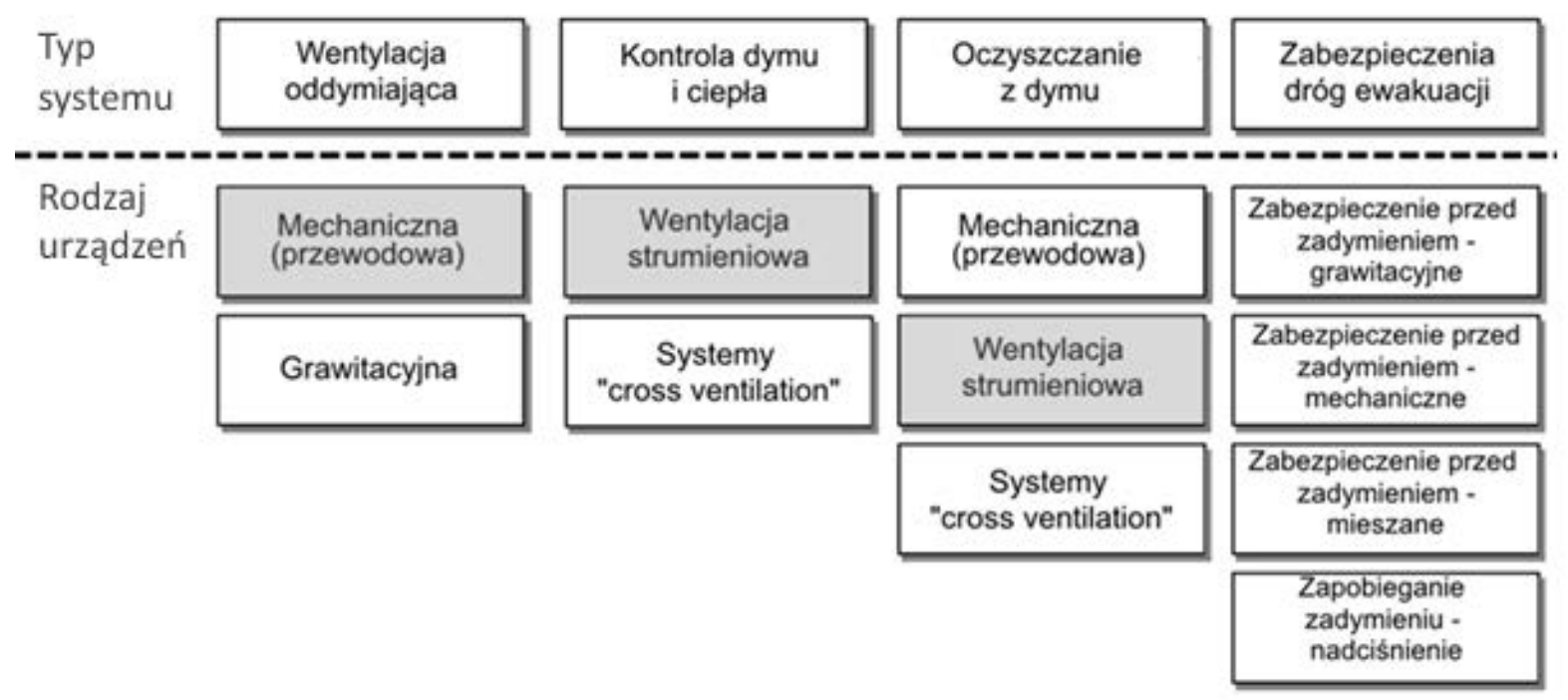

Ryc. 1. Podział systemów wentylacji pożarowej z uwagi na typ oraz rodzaj wykorzystanych urządzeń, z zaznaczeniem systemów najczęściej wykorzystywanych w garażach zamkniętych

Fig. 1. Fire ventilation systems based on their purpose and the type of solution, most popular systems used in car parks grayed out Źródło: Opracowanie własne.

Source: Own elaboration. 


\section{System wentylacji oddymiającej}
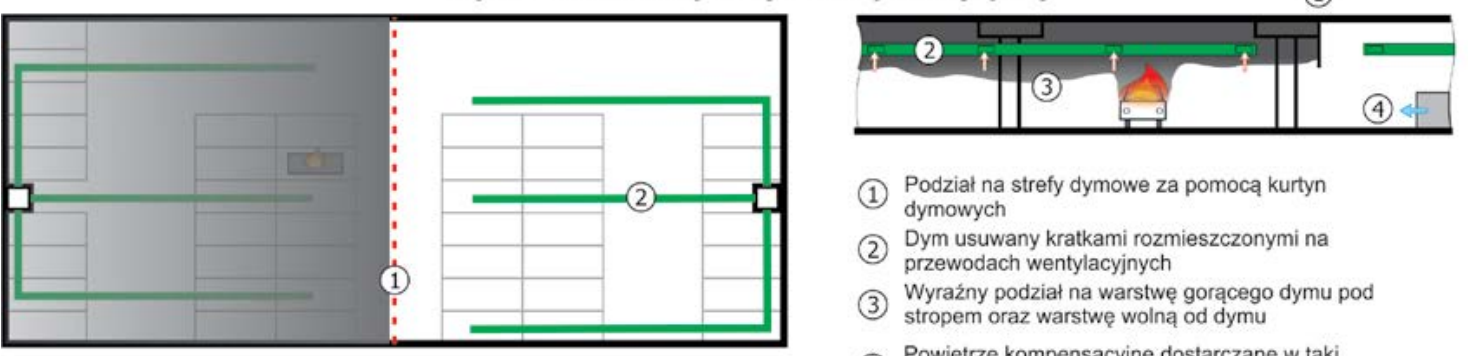

1) Podział na strefy dymowe za pomocą kurtyn dymowych

(2) Dym usuwany kratkami rozmieszczonymi na przewodach wentylacyjnych

Wyraźny podział na warstwẹ gorącego dymu pod

3) stropem oraz warstwę wolną od dymu

(4) Powietrze kompensacyjne dostarczane $w$ tak
sposób, aby nie powodować opadania dymu

\section{System wentylacji strumieniowej - oczyszczania z dymu}
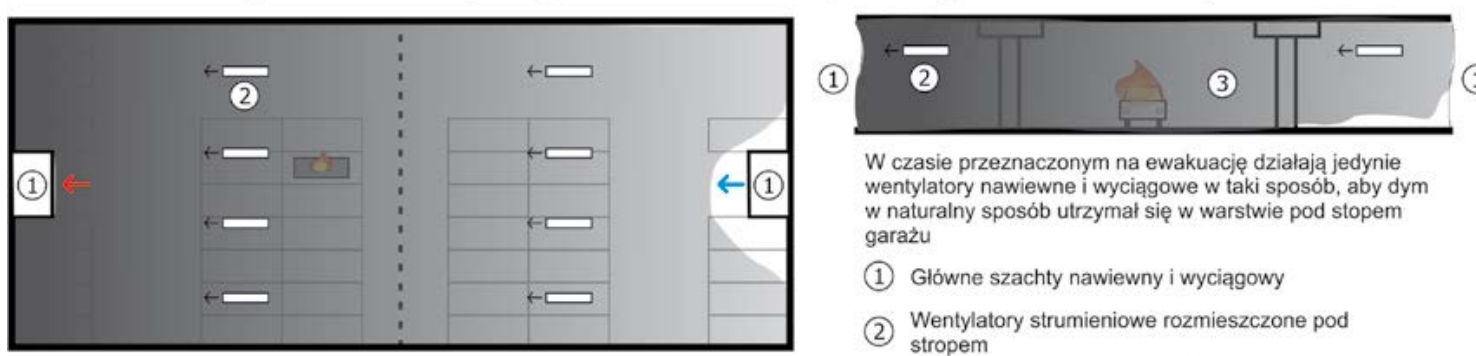

W czasie przeznaczonym na ewakuacje działają jedynie w naturalny sposób utrzymał się w warstwie pod stopem garažu

(1) Glówne szachty nawiewny i wyciągowy

2) Wentylatory strumieniowe rozmieszczone pod stropem

(3) Dym rozprzestrzenia się w całym obszarze garażu, jednak jego temperatura jest ograniczana dziẹk mieszaniu z powietrzem nkompensującym

\section{System wentylacji strumieniowej - kontrola dymu i ciepła}
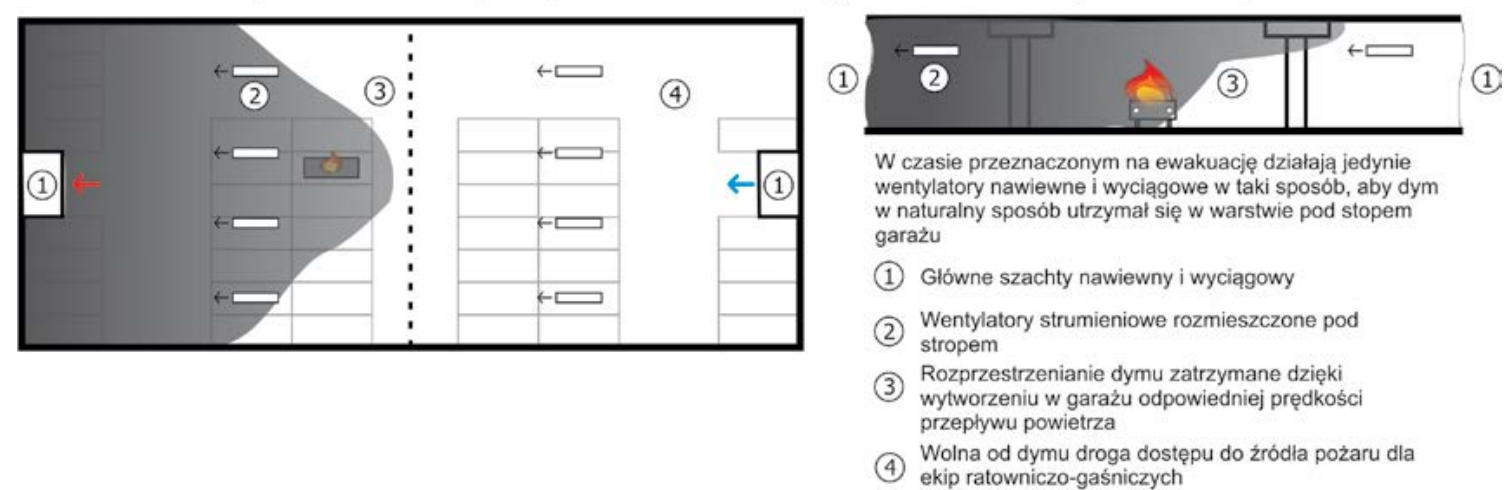

Ryc. 2. Podstawowe zasady działania systemów wentylacji pożarowej garaży zamkniętych [22]

Fig. 2. Principals of operation of basic fire ventilation systems in enclosed car parks [22]

Projektując system wentylacji pożarowej, należy pamiętać, że możliwa jest sytuacja, w której system wentylacji pożarowej o poprawnie dobranych parametrach działania z uwagi na specyficzne uwarunkowania architektoniczne może okazać się nieskuteczny [23]. Także dowolna wymiana wcześniej zaprojektowanego rodzaju systemu na inny (np. zmiana z przewodowej wentylacji oddymiającej na system wentylacji strumieniowej działający jako oczyszczanie z dymu) bez żadnego przeprojektowania szachtów lub innych kluczowych elementów systemu nie jest możliwa. W związku z powyższym dla każdego projektu systemu wentylacji pożarowej oraz istotnych zmian wprowadzanych w projekcie zaleca się przeprowadzenie analiz CFD rozprzestrzeniania się dymu i ciepła w garażu w celu oceny skuteczności funkcjonowania każdego systemu wentylacji pożarowej, w trakcie której możliwa jest ocena skuteczności działania syste- mu. Dodatkowo w celu weryfikacji skuteczności działania systemu w ukończonym obiekcie budowlanym przed oddaniem go do użytkowania zaleca się przeprowadzenie prób z gorącym dymem. W czasie prób oceniana jest współpraca systemu wentylacji pożarowej w obiekcie $\mathrm{z}$ innymi systemami bezpieczeństwa pożarowego w budynku, wraz z pełną weryfikacją poprawności realizacji scenariusza pożarowego.

\section{Analizy numeryczne rozprzestrzeniania się dymu i ciepła w garażu}

Wykorzystanie mechaniki płynów w inżynierii bezpieczeństwa pożarowego stało się dziś nieodłącznym elementem większości projektów systemów wentylacji pożarowej. Przede wszystkim analiza przepływu dwóch płynów różniących się gęstością (temperaturą) to doskonałe pole do praktycznego zastosowania metody obliczenio- 
wej mechaniki płynów (CFD, ang. Computational Fluid Dynamics). Nieustanny wzrost dostępnej mocy obliczeniowej komputerów osobistych spowodował obserwowany w ostatnich latach wzrost liczby zarówno podmiotów zajmujących się analizami numerycznymi w bezpieczeństwie pożarowym, jak i popularyzację samych analiz [24].

Pierwszym opisanym wykorzystaniem metody numerycznej w rozwiązywaniu równań opisujących przepływ płynu były prowadzone w latach 20 . XX wieku prace Lewisa Richardsona, których przeznaczeniem było opracowanie modeli przewidywania pogody [25]. Rozwiązywanie zagadnień komputerowej mechaniki płynów polega na rozwiązywaniu układów równań różniczkowych opisujących analizowane zjawiska. Podstawowymi równaniami, rozwiązywanymi we wszystkich zadaniach, są równania opisujące pole ciśnienia i prędkości (równanie ciągłości) i równania ruchu Naviera-Stokesa. W przypadku analiz rozprzestrzeniania się dymu i ciepła rozwiązywane są dodatkowe równania zachowania - energii, promieniowania i transportu dymu. W publikacji poruszono zagadnienia związane z podstawowym układem równań metody CFD, modelowaniem pożaru, promieniowania i analizą wyników. Celowo pominięto zagadnienia związane $\mathrm{z}$ metodami dyskretyzacji czy schematami prowadzenia obliczeń. Więcej informacji na temat wykorzystania metody CFD $\mathrm{w}$ inżynierii bezpieczeństwa pożarowego zawarto $\mathrm{w}$ publikacjach [25-29], podczas gdy podstawy merytoryczne metody można odnaleźć w publikacjach [30-35].

\subsection{Układ równań metody CFD na potrzeby analiz rozprzestrzeniania się dymu i ciepła}

Podstawowy układ równań wykorzystywany w metodzie obliczeniowej mechaniki płynów wykorzystywanej w analizach na potrzeby bezpieczeństwa pożarowego W najprostszy sposób przedstawił McGrattan [25]:

- równanie zachowania masy, warunkujące przepływ w badanym obszarze. Zachowanie masy oznacza, że masa nie powstaje ani nie ginie w czasie obliczeń. Innymi słowy, zmiana gęstości $\mathrm{w}$ dowolnej objętości jest równa masowemu przepływowi przez jej granice. Dla rozwiązań związanych z bezpieczeństwem pożarowym równanie zachowania masy jest rozbudowane o równania transportu składników mieszaniny pozwalające określić istotne $\mathrm{z}$ punktu widzenia rozwiązania stężenia tlenu, paliwa oraz produktów spalania.

$$
\frac{\partial p}{\partial t}+\nabla \rho \boldsymbol{u}=0
$$

Równanie masy może być także przedstawione jako równanie transportu składników mieszaniny, nazywane także równaniem zachowania składników:

$$
\frac{\partial\left(\rho Y_{i}\right)}{\partial t}+\nabla\left(\rho Y_{i} \boldsymbol{u}\right)=\nabla \rho D_{i} \nabla Y_{i}+\dot{m}_{i}^{\prime \prime \prime}
$$

- równanie zachowania momentu, będące wyrazem zachowania drugiego prawa ruchu Newtona. Siły powodujące przepływ płynu składają się z pola ciśnienia $\nabla \mathrm{p}$, tarcia (w formie tensora $\tau$ ) oraz zewnętrznych sił $f$ (takich jak np. siła wyporu). Przedstawione równanie rozwiązywane jest dla każdego kierunku ruchu.

$$
\frac{\partial(\rho \boldsymbol{u})}{\partial t}+\nabla(\rho \boldsymbol{u} \boldsymbol{u})=-\nabla \rho+\boldsymbol{f}+\nabla \boldsymbol{\tau}
$$

- równanie zachowania energii, które określa, że entalpia w dowolnym punkcie zmienia się zależnie od strumienia energii wpływającego do objętości kontrolnej. Ponadto także wewnątrz objętości ciepło może być generowane w wyniku chemicznej reakcji spalania oraz być dostarczane w wyniku tarcia, oddziaływania ciśnienia, dyssypacji energii kinetycznej czy promieniowania. W zastosowaniach związanych $\mathrm{z}$ bezpieczeństwem pożarowym człon odpowiadający za oddziaływanie pola ciśnienia oraz dyssypację energii kinetycznej zazwyczaj pomija się.

$$
\begin{gathered}
\frac{\partial(\rho h)}{\partial t}+\nabla \rho h \boldsymbol{u}=\frac{D p}{D t}+\dot{q}^{\prime \prime \prime}-\nabla \boldsymbol{q}+\epsilon \\
h=\int_{T_{0}}^{T} c_{p} d T
\end{gathered}
$$

- aby przedstawiony układ równań był domknięty, niezbędne jest opisanie powiązań pomiędzy ciśnieniem i gęstością, co w przypadku zagadnień związanych $\mathrm{z}$ bezpieczeństwem pożarowym w wystarczającym stopniu opisuje równanie gazu doskonałego

$$
\begin{gathered}
p=\frac{\rho R T}{\bar{W}} \\
\bar{W}=\frac{1}{\Sigma\left(\frac{Y_{i}}{W_{i}}\right)}
\end{gathered}
$$

Rozwiązywane w ramach analiz rozprzestrzeniania się dymu i ciepła zagadnienia charakteryzuje przepływ o dużej turbulencji. W związku z tym do opisu pola prędkości i ciśnienia przyjmuje znacznie bardziej skomplikowaną formę. W celu jego uproszczenia można wykorzystać np. metodę modelowania przepływu RANS (Reynolds Average Navier-Stokes). W metodzie tej turbulencja uwzględniana jest przez dodatkowe człony i równania wynikające $\mathrm{z}$ uśrednienia $\mathrm{w}$ czasie parametrów przepływu. Poza metodą RANS do modelowania przepływów wykorzystywane są metody: DNS (Direct Navier-Stokes), LES (Large Eddy Simulation) oraz DVM (Discrete Vortex Methods). W zagadnieniach inżynierii bezpieczeństwa pożarowego do modelowania przepływów turbulentnych najczęściej stosuje się model turbulencji k-E w wersji ,standard”. Szczegółowy opis modelu turbulencji k- $\varepsilon$ znajduje się m.in. w pracach Błazik-Borowa [36], Launder i Sharma [37],[38] i Wilcox [39].

Drugi z popularnych modeli turbulencji to model LES (ang. Large Eddy Simulation), opierający się na teorii dużych wirów. Działanie tego modelu jest wyjątkowo wrażliwe na rozmiar siatki numerycznej wykorzystywanej w obliczeniach, przez co wymaga wykorzystania dokład- 
niejszej siatki obliczeniowej oraz krótszego kroku czasowego obliczeń, w porównaniu do obliczeń z zastosowaniem modelu RANS [24]. Najistotniejszym parametrem charakteryzującym obliczenia $\mathrm{z}$ zastosowaniem metody LES jest tzw. filtr Smagorinskiego, czyli wielkość wirów, które w obliczeniach są pomijane. Wybór modelu przepływu turbulentnego, często sprowadzający się do wyboru oprogramowania, w którym prowadzone będą analizy numeryczne, ma kluczowe znaczenie przy rozwiązywaniu zagadnień związanych z przepływem wymuszonym przy oddziaływaniu pożaru, w szczególności w odniesieniu do systemów wentylacji strumieniowej. Model LES zaimplementowany np. w programie FDS w zależności od przyjętego wymiaru siatki może pomijać wiry istotnie wpływające na przepływ powietrza w pobliżu elementów wentylacji pożarowej. W związku z powyższym analizie $\mathrm{z}$ wykorzystaniem modelu turbulencji LES powinna towarzyszyć analiza a posteriori poprawności przyjętej siatki numerycznej poprzez np. sprawdzenie tzw. skali nierozwiązanej energii turbulencji (ang. turbulence resolution) [40],[41]. Wartość tego parametru nie powinna przekraczać $20 \% \mathrm{w}$ obszarze w pobliżu elementów systemu wentylacji pożarowej. Dodatkowo z uwagi na powiązania pomiędzy modelem przepływu a modelem spalania, błędnie dobrany rozmiar siatki, a przez to złe rozwiązanie przepływu w pobliżu powierzchni dostarczającej paliwo może wpłynąć na generowaną w pożarze ilość ciepła oraz rozkład temperatury w kolumnie konwekcyjnej.

\subsection{Modelowanie pożaru}

Modelowanie procesów rozwoju pożaru i rozprzestrzeniania się dymu i ciepła w obiektach budowlanych z wykorzystaniem komputerowej mechaniki płynów wymaga zdefiniowania modelu źródła pożaru oraz uzupeł- nienia powyższej przestawionego układu równań o równanie bilansu energii i równanie transportu dymu.

Źródło ciepła i dymu może być opisane z wykorzystaniem trzech dostępnych metod:

- powierzchniowe źródło ciepła i dymu, w którym energia oraz produkty spalania (dym, gazy toksyczne) uwalniane są z zadanej powierzchni odzwierciedlającej powierzchnię pożaru;

- objętościowe źródło ciepła i dymu, w którym energia oraz produkty spalania (dym, gazy toksyczne) uwalniane są wewnątrz określonej objętości odzwierciedlającej objętość pożaru;

- modele spalania, w których uwolnienie energii oraz powstanie dymu i innych produktów spalania jest efektem reakcji chemicznej. Paliwo jest uwalniane z zadanej powierzchni lub w zadanej objętości, a możliwość zajścia reakcji chemicznej warunkowana jest dostarczeniem minimalnej energii zapłonu, dostępnością paliwa i tlenu oraz stechiometrią reakcji, przy czym jeżeli wynikiem analizy ma być także stężenie tlenku węgla (II), wykorzystana reakcja chemiczna powinna być dwustopniowa.

Bez względu na rodzaj modelu użytkownik prowadzący obliczenia musi zdefiniować parametry [24]:

- mocy pożaru, czyli ilości ciepła powstającego w czasie, najczęściej przedstawianej w formie krzywej HRR (ang. Heat Release Rate), jest to wartość zmienna w czasie;

- efektywnego ciepła spalania paliwa $\Delta \mathrm{H}_{\mathrm{c}}^{\text {eft }}$, czyli parametru określającego, jaka ilość ciepła powstaje w spaleniu określonej masy paliwa, jest to wartość stała opisująca paliwo, uwzględniająca jego otoczenie;

Tabela 1.

Porównanie całkowitej wydzielonej energii [GJ] w czasie wybranych testów pożarowych samochodów osobowych w pełnej skali, na podstawie [42] oraz [43-52]

Table 1.

Comparison of total energy released in chosen full scale fire tests of cars, based on [42] and [43-52]

\begin{tabular}{|l|c|c|c|c|}
\hline $\begin{array}{c}\text { Jednostka badawcza / } \\
\text { Testing unit }\end{array}$ & $\begin{array}{c}\text { Rok / Rok prod. } \\
\text { samochodu } \\
\text { Year / Car date of } \\
\text { production }\end{array}$ & $\begin{array}{c}\text { Ilość po- } \\
\text { jazdów / } \\
\text { Number of } \\
\text { cars }\end{array}$ & $\begin{array}{c}\text { Szczytowe HRR / Peak } \\
\text { HRR [MW] }\end{array}$ & $\begin{array}{c}\text { Catkowita wydzielona } \\
\text { energia / total energy } \\
\text { released [GJ] }\end{array}$ \\
\hline VTT & $1994 /\left(1970^{1}\right)$ & 1 & $1,5-2,0$ & $3,0-3,9$ \\
\hline FRS-BRE & $1995 /(1982)$ & 1 & 8,2 & 4,0 \\
\hline FRS-BRE & $1995 /(1986)$ & 1 & 4,4 & 4,95 \\
\hline CTICM & 1997 & $1-2$ & $1,7-10,0$ & $3,1-8,9$ \\
\hline MPA & $1997 /\left(1980^{1}\right)$ & 1 & 3,6 & 3,2 \\
\hline MPA & $1997 /\left(1990^{1}\right)$ & 1 & 1,7 & 8,0 \\
\hline MPA & $1997 /\left(1990^{1}\right)$ & 1 & 4,4 & 6,8 \\
\hline CTICM & $2004 /(1994)$ & 1 & 9,8 & 7,0 \\
\hline CTICM & $2004 /(1994)$ & 1 & 8,2 & 3,9 \\
\hline SP & 2004 & 1 & 3,5 & $4,8-5,0$ \\
\hline BRI & 2008 & 1 & $2,0-3,5$ & - \\
\hline BRE & 2008 & 1 & 4,8 & 3,1 \\
\hline
\end{tabular}

${ }^{1}$ nieznana data produkcji samochodu / unkwnown date of productions of the cars 
- współczynnika generacji sadzy Ysoot określającego, jak dużo widocznego dymu powstaje ze spalenia określonej masy paliwa, jest to wartość stała opisująca paliwo, uwzględniająca jego otoczenie.

Przedstawione parametry źródła pożaru w odniesieniu do pożarów samochodów osobowych są odwzorowaniem wyników licznych badań nad ilością ciepła wydzielaną w pożarze pojazdu. Maksymalny strumień wydzielanego ciepła (ang. heat release rate, HRR) w dużej mierze zależy od sposobu prowadzenia badania (np. miejsce zapłonu) oraz momentu, w którym uszkodzeniu ulegnie zbiornik z paliwem, podczas gdy parametr całkowitej energii wydzielonej w trakcie pożaru samochodu zależy w największej mierze od całkowitej masy oraz rodzaju materiałów palnych znajdujących się w samochodzie. W ana- lizach CFD parametrem wykorzystywanym będzie wartość HRR, jednak analiza całkowitej wydzielonej energii w pełniejszy sposób obrazuje zagrożenie, jakim jest pożar samochodu. Wartość całkowitej energii wydzielonej w badaniach prowadzonych nad samochodami osobowymi o podobnych gabarytach w latach 1994-2008 przedstawiono w tabeli 1 . Wyniki te opracowano oparto na pracy Jannsens [42] oraz publikacjach podsumowujących przeprowadzone badania [42-52]. Na szczególne podkreślenie zasługują publikacje Van Oerle N. et al. [48] stanowiące podstawę merytoryczną przytoczonych w dalszej części publikacji krzywych HRR zalecanych do stosowania $w$ analizach oraz publikacja BRE [52].

$\mathrm{Z}$ powyższego porównania wyników badań można wyciągnąć wniosek, iż nowoczesne samochody zawierają coraz większą ilość materiałów palnych. Szacowana

Tabela 2.

Źródło zapłonu oraz sposób wentylowania przedziału pasażerskiego w badaniach opracowane na podstawie [42] oraz [43-52]

Table 2.

Source of ignition and type of passenger compartment ventilation in fire tests, based on [42] and [43-52]

\begin{tabular}{|c|c|c|c|c|}
\hline $\begin{array}{l}\text { Nazwa jednostki } \\
\text { badawczej / fire } \\
\text { testing unit }\end{array}$ & $\begin{array}{l}\text { Rok / } \\
\text { Date }\end{array}$ & \begin{tabular}{|c|} 
Czas \\
trwania/ \\
lenght of \\
the test \\
[min] \\
\end{tabular} & $\begin{array}{l}\text { Źródło zapłonu / } \\
\text { Source of the ignition }\end{array}$ & $\begin{array}{l}\text { Wentylacja przedziału pasażerskiego } \\
\text { / Passenger compartment ventilation }\end{array}$ \\
\hline $\begin{array}{l}\text { VTT Building } \\
\text { Technology }\end{array}$ & 1994 & 69,8 & $\begin{array}{l}1,51 \text { heptanu w tacy pod lewym } \\
\text { przednim siedzeniem / } 1.51 \text { of } \\
\text { heptane in tray under left front } \\
\text { seat }\end{array}$ & $\begin{array}{l}\text { Lewe przednie drzwi uchylone } \mathrm{z} \\
\text { oknem otwartym, prawe okno uchy- } \\
\text { lone o } 5 \mathrm{~cm} / \text { Left front window open } \\
\text { wide, right window open for } 5 \mathrm{~cm} \\
\end{array}$ \\
\hline $\begin{array}{l}\text { VTT Building } \\
\text { Technology }\end{array}$ & 1994 & 48,6 & $\begin{array}{l}31 \text { heptanu w tacy pod komorą } \\
\text { silnika / } 31 \text { heptane in tray under } \\
\text { the hood }\end{array}$ & $\begin{array}{l}\text { Lewe przednie okno otwarte, pozostałe } \\
\text { uchylone o } 5 \mathrm{~cm} / \text { Left front window } \\
\text { open wide, other windows open for } 5 \\
\mathrm{~cm}\end{array}$ \\
\hline $\begin{array}{l}\text { VTT Building } \\
\text { Technology }\end{array}$ & 1994 & 88,7 & $\begin{array}{l}31 \text { heptanu w tacy pod komora } \\
\text { silnika / } 31 \text { heptane in tray under } \\
\text { the hood }\end{array}$ & $\begin{array}{l}\text { Lewe przednie okno otwarte, pozostałe } \\
\text { uchylone o } 5 \mathrm{~cm} / \text { Left front window } \\
\text { open wide, other windows open for } 5 \\
\mathrm{~cm}\end{array}$ \\
\hline TU Braunschweig & 1992 & 50,1 & brak danych / no data & brak danych / no data \\
\hline $\mathrm{BRE}$ & 1995 & 38,6 & $\begin{array}{l}400 \mathrm{ml} \text { benzyny w tacy w komo- } \\
\text { rze silnika / } 0.41 \text { gasoline in engi- } \\
\text { ne chamber }\end{array}$ & $\begin{array}{l}\text { Okna kierowcy i pasażera otwarte / } \\
\text { front windows open }\end{array}$ \\
\hline CTICM & 1997 & 20,9 & $\begin{array}{l}1,51 \text { benzyny w tacy pod lewym } \\
\text { przednim siedzeniem / } 1.51 \text { of ga- } \\
\text { soline in tray under left front seat }\end{array}$ & no data \\
\hline CTICM & 1997 & 51,1 & $\begin{array}{l}\text { 1,5 } 1 \text { benzyny w tacy pod lewym } \\
\text { przednim siedzeniem / } 1.51 \text { of ga- } \\
\text { soline in tray under left front seat }\end{array}$ & no data \\
\hline CTICM & 1997 & 42,8 & $\begin{array}{l}11 \text { benzyny w tacy pod skrzynią } \\
\text { biegów / } 11 \text { gasoline in tray under } \\
\text { gearbox }\end{array}$ & no data \\
\hline SP & 1998 & 25,2 & $\begin{array}{l}0,2 \text { rozpuszczalnika mineralnego } \\
\text { na siedzeniu kierowcy / } 0,2 \text { of } \\
\text { flammable liquid on drivers seat }\end{array}$ & no data \\
\hline $\mathrm{TNO}$ & 1999 & 17,6 & no data & no data \\
\hline $\mathrm{TNO}$ & 1999 & 32,8 & no data & no data \\
\hline TNO & 1999 & 27,7 & no data & no data \\
\hline MPA & 1997 & 24,6 & $\begin{array}{l}\text { 0,25 l izopropanolu pod przednim } \\
\text { siedzeniem / 0,25 } 1 \text { iso-propane } \\
\text { alcohol under front seat }\end{array}$ & $\begin{array}{l}\text { Lekko uchylone okna / windows sli- } \\
\text { ghtly open }\end{array}$ \\
\hline
\end{tabular}




\begin{tabular}{|c|c|c|c|c|}
\hline $\begin{array}{l}\text { Nazwa jednostki } \\
\text { badawczej / fire } \\
\text { testing unit }\end{array}$ & $\begin{array}{l}\text { Rok / } \\
\text { Date }\end{array}$ & \begin{tabular}{|c|} 
Czas \\
trwania/ \\
lenght of \\
the test \\
[min] \\
\end{tabular} & $\begin{array}{l}\text { Źródło zapłonu / } \\
\text { Source of the ignition }\end{array}$ & $\begin{array}{l}\text { Wentylacja przedziału pasażerskiego } \\
\text { / Passenger compartment ventilation }\end{array}$ \\
\hline MPA & 1997 & 56,9 & $\begin{array}{l}\text { 0,25 } 1 \text { izopropanolu pod przednim } \\
\text { siedzeniem / } 0,251 \text { iso-propane } \\
\text { alcohol under front seat }\end{array}$ & $\begin{array}{l}\text { Lekko uchylone okna / windows sli- } \\
\text { ghtly open }\end{array}$ \\
\hline MPA & 1997 & 47,4 & $\begin{array}{l}\text { 0,25 l izopropanolu pod przednim } \\
\text { siedzeniem / 0,25 } 1 \text { iso-propane } \\
\text { alcohol under front seat }\end{array}$ & $\begin{array}{l}\text { Lekko uchylone okna / windows sli- } \\
\text { ghtly open }\end{array}$ \\
\hline \begin{tabular}{|l|} 
NIST \\
\end{tabular} & 1999 & 38,8 & $\begin{array}{l}21 \text { benzyny rozlane na przednim } \\
\text { siedzeniu / } 21 \text { of gasoline spilled } \\
\text { on front seat }\end{array}$ & $\begin{array}{l}\text { Otwarte okna kierowcy i pasażera / } \\
\text { front windows open }\end{array}$ \\
\hline NIST & 1999 & 44,7 & $\begin{array}{l}21 \text { benzyny rozlane na przednim } \\
\text { siedzeniu / } 21 \text { of gasoline spilled } \\
\text { on front seat }\end{array}$ & $\begin{array}{l}\text { Otwarte okna kierowcy i pasażera / } \\
\text { front windows open }\end{array}$ \\
\hline BRI & 2008 & 48,4 & $\begin{array}{l}\text { Materiał zamoczony w metanolu / } \\
\text { textile damped in methyl alcohol }\end{array}$ & $\begin{array}{l}\text { Okna uchylone o } 10 \mathrm{~cm} / \text { windows } \\
\text { open for } 10 \mathrm{~cm}\end{array}$ \\
\hline BRI & 2008 & 80,6 & $\begin{array}{l}\text { Materiał zamoczony w metanolu / } \\
\text { textile damped in methyl alcohol }\end{array}$ & $\begin{array}{l}\text { Okna uchylone o } 10 \mathrm{~cm} / \text { windows } \\
\text { open for } 10 \mathrm{~cm}\end{array}$ \\
\hline BRI & 2008 & 46,9 & $\begin{array}{l}\text { Materiał zamoczony w metanolu / } \\
\text { textile damped in methyl alcohol }\end{array}$ & $\begin{array}{l}\text { Okna uchylone o } 10 \mathrm{~cm} / \text { windows } \\
\text { open for } 10 \mathrm{~cm}\end{array}$ \\
\hline BRI & 2008 & 47,5 & $\begin{array}{l}\text { Materiał zamoczony w metanolu / } \\
\text { textile damped in methyl alcohol }\end{array}$ & $\begin{array}{l}\text { Okna uchylone o } 10 \mathrm{~cm} / \text { windows } \\
\text { open for } 10 \mathrm{~cm}\end{array}$ \\
\hline CTICM & 2003 & 113,9 & $\begin{array}{l}\text { 1,5 l benzyny w tacy / 1,5 1 of } \\
\text { gasoline in tray }\end{array}$ & $\begin{array}{l}\text { Okno pasażera otwarte / passenger } \\
\text { window open }\end{array}$ \\
\hline
\end{tabular}

w roku 1998 ilość tworzyw sztucznych w samochodzie osobowym wynosiła około $115 \mathrm{~kg}$ [53]. Do wartości tej należy dodać około $50 \mathrm{~kg}$ benzyny oraz innych cieczy palnych znajdujących się w pojeździe, co sumarycznie daje około $165 \mathrm{~kg}$ materiałów palnych w samochodzie. W pracy [54] przedstawiono dane pochodzące ze zezłomowanych pojazdów i określono, że masa elementów z tworzyw sztucznych w samochodach wynosi około $100 \mathrm{~kg}$. Od czasu przeprowadzenia tych badań ilość materiałów palnych w pojazdach mogła wzrosnąć do około 150-200 kg [55]. Niestety w prowadzonych obecnie badaniach nad rozprzestrzenianiem się ognia w samochodach testowane są modele sprzed kilku lat. W trakcie prac BRE w latach 2007-2010 [52] przeprowadzono 11 pożarów testowych, w których wykorzystano 20 pojazdów wyprodukowanych w latach 1998-2004. W powyższym programie badawczym przyjęto, że w chwili badania samochody mogą mieć co najwyżej 5 lat bądź być wciąż produkowane $\mathrm{w}$ niezmienionej formie.

Średni czas trwania pożaru do samoistnego ugaszenia w analizowanych badaniach wynosił 48,3 minut. Najkrótszy odnotowany pożar trwał 17,6 minuty, a najdłuższy 113,9 minuty. Czas trwania eksperymentu w dużym stopniu zależał od źródła zapłonu oraz sposobu wentylacji przedziału pasażerskiego. Dane te dla opisywanych badań przedstawiono w tabeli 2.

Przy założeniach, że strumień wydzielanego ciepła w pożarze pojedynczego pojazdu jest stały w czasie, równy $4 \mathrm{MW}$, co odpowiada założeniom projektowym wykorzystywanym do projektowania instalacji wentylacji oddymiającej, a całkowite wydzielone ciepło równe 9500 MJ, co odpowiada pożarowi pojedynczego samochodu klasy 3 [45], całkowity oczekiwany czas spalania wyno- si 39,6 minuty. Czas ten nie uwzględnia czasu niezbędnego na rozprzestrzenienie się ognia $\mathrm{w}$ obrębie samochodu oraz fazy wygaszania. Wartość ta jest zbliżona do wartości średniej równej 48,3 minuty pochodzącej z badań przedstawionych w tabeli 2 .

Poza mocą pożaru, czasem jego trwania i całkowitą wydzieloną w pożarze energią, istotnym parametrem ważnym dla poprawnej analizy rozprzestrzeniania się dymu i ciepła w garażach zamkniętych jest produkcja sadzy i toksycznych produktów spalania. Wartości tych parametrów opracowane na podstawie [56] przedstawiono w tabeli 3 .

Tabela 3.

Wartości produkcji sadzy, CO2 oraz CO dla wybranych tworzyw sztucznych, opracowano na podstawie [56]

Table 3.

Soot, $\mathrm{CO}_{2}$ and $\mathrm{CO}$ yields for various plastics, based on [56]

\begin{tabular}{|l|l|l|l|}
\hline \multirow{2}{*}{ Material / Material } & \multicolumn{3}{|l|}{ Produkcja / Production (g/g) } \\
\cline { 2 - 4 } & Sadza / Soot & CO2 & CO \\
\hline HDPE & 0,035 & $\mathrm{~b} / \mathrm{d}$ & $\mathrm{b} / \mathrm{d}$ \\
\hline PE & 0,027 & 2,76 & 0,024 \\
\hline PP & 0,046 & 2,76 & 0,024 \\
\hline PS & 0,085 & 2,33 & 0,060 \\
\hline $\begin{array}{l}\text { Pianka PS / PS } \\
\text { Foam }\end{array}$ & 0,128 & 2,32 & 0,061 \\
\hline $\begin{array}{l}\text { Pianka PS (FR) / PS } \\
\text { Foam (FR) }\end{array}$ & 0,136 & $\mathrm{~b} / \mathrm{d}$ & $\mathrm{b} / \mathrm{d}$ \\
\hline PMMA & 0,010 & 2,12 & 0,01 \\
\hline ABS & 0,066 & $\mathrm{~b} / \mathrm{d}$ & $\mathrm{b} / \mathrm{d}$ \\
\hline ABS-PVC & 0,124 & $\mathrm{~b} / \mathrm{d}$ & $\mathrm{b} / \mathrm{d}$ \\
\hline PVC & $0,076-0,112$ & 0,46 & 0,063 \\
\hline
\end{tabular}


$\mathrm{Na}$ potrzeby inżynierskich analiz rozprzestrzeniania się dymu i ciepła w Zakładzie Badań Ogniowych ITB wykorzystywane są krzywe rozwoju pożaru jednego lub trzech samochodów osobowych zaczerpnięte $\mathrm{z}$ holenderskiej normy NEN 6098:2010 Rookbeheersingssystemen voor mechanisch geventileerde parkeergarages [16] i przedstawione zostały na ryc. 3 i 4 . Krzywe te sa wynikiem programu badań nad rozwojem pożaru w garażach zamkniętych przeprowadzonego w 1999 roku przez holenderską organizację TNO [48].

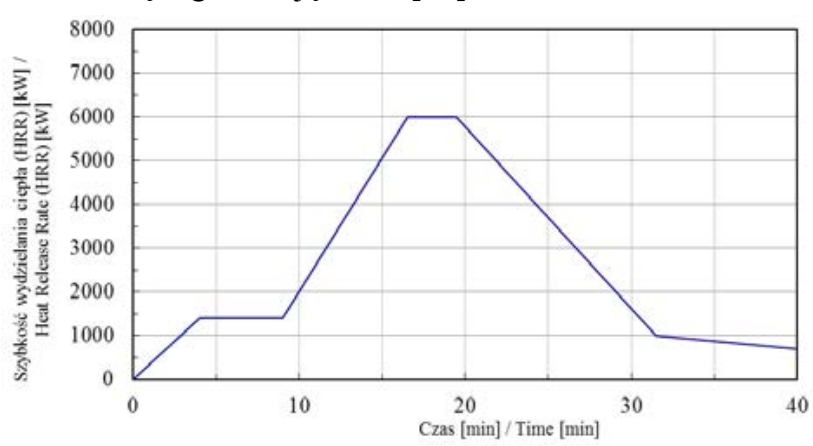

Ryc. 3. Krzywa rozwoju pożaru pojedynczego samochodu osobowego przyjmowana do analiz CFD [16]

Fig. 3. HRR curve for a single vehicle used in CFD analysis [16]

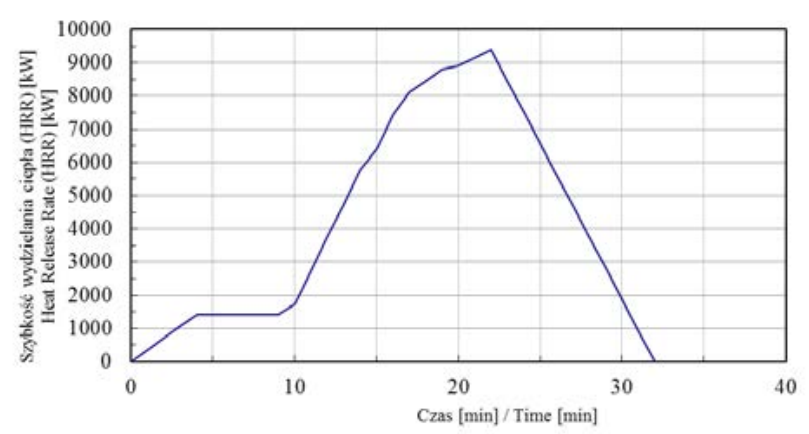

Ryc. 4. Krzywa rozwoju pożaru trzech samochodów osobowych przyjmowana do analiz CFD [16]

Fig. 3. HRR curve for three vehicles used in CFD analysis [16]

\subsection{Modele promieniowania cieplnego}

Transport energii na drodze promieniowania jest kluczowy dla poprawnego rozwiązania przepływów w warunkach pożaru $\mathrm{z}$ uwagi na wysoką temperaturę oraz wysoką wartość współczynnika pochłaniania światła przez dym. Wykorzystywany model promieniowania powinien umożliwiać odwzorowanie strumienia promieniowania zwróconego od warstwy dymu w kierunku podłogi w celu oceny zagrożenia, jakie ono stwarza dla osób ewakuujących się oraz ekip ratowniczych.

Poprawne rozwiązanie transferu ciepła na drodze promieniowania jest trudne, ponieważ po pierwsze energia na tej drodze transportowana jest niemal natychmiast w całej badanej objętości, oraz po drugie energia wypromieniowywana jest z każdej objętości skończonej we wszystkich możliwych kierunkach. Zakładając, że gaz w objętościach kontrolnych jest ciałem szarym, najprostszy model transportu ciepła na drodze promieniowania można przedstawić jako [25]:

$$
s \nabla I(x, s)=\epsilon(x)\left[\left(I_{b}(x)-I(x, s)\right]\right.
$$

gdzie I jest intensywnością promieniowania, funkcją zarówno położenia (x), jak i kierunku (s). Założenie ciała szarego pozwala pominąć fakt, że intensywność promieniowania I jest także funkcją długości fali, tak jak współczynnik emisyjności $\varepsilon$ i źródło $\mathrm{I}_{b}$. Opis współczynnika emisyjności jest funkcją stężenia cząsteczek sadzy w danej objętości kontrolnej. Rozwiązanie promieniowania powinno odbywać się dla skończonej liczby kątów emisji. Liczba tych kątów jest olbrzymia, co w połączeniu $\mathrm{z}$ równie dużą liczbą objętości kontrolnych powoduje tak wysokie wymagania sprzętowe niezbędne dla poprawnego rozwiązania promieniowania. Alternatywą dla bezpośredniego rozwiązania promieniowania są modele ,transportu promieniowania”, których przykładem jest model $\mathrm{P} 1$. W modelu P1 równanie strumienia ciepła na drodze promieniowania ma postać [57]:

$$
\begin{gathered}
\Gamma=-\frac{1}{3(\epsilon+\sigma)-C \sigma} \\
q_{r}=-\Gamma \nabla G
\end{gathered}
$$

gdzie $\varepsilon$ jest współczynnikiem emisyjności, $\sigma$ jest współczynnikiem rozpraszania, $\mathrm{G}$ jest natężeniem promieniowania, a C współczynnikiem opisanym przyjmującym wartość od -1 do 1 wyznaczanym dla każdego elementu skończonego. Wartość dodatnia współczynnika C oznacza, że z objętości skończonej wypromieniowane jest więcej energii, niż otrzymuje ona na drodze promieniowania. Dzięki zastosowaniu modelu P1 przepływ energii na drodze promieniowania nie jest rozwiązywany dla wszystkich kątów emisji, ale raczej w formie równania transportu promieniowania pomiędzy objętościami skończonymi:

$$
\nabla q_{r}+4 \pi\left(\epsilon\left(\frac{\sigma T^{4}}{\pi}+E_{p}\right)-\left(\epsilon+\epsilon_{o}\right) G=0\right.
$$

gdzie $\mathrm{E}_{\mathrm{p}}$ to emisyjność zastępcza a $\varepsilon_{\mathrm{p}}$ to zastępczy współczynnik absorpcyjności, wyznaczany z wykorzystaniem kolejnego układu równań, przedstawionego w szczegółach w [57].

Bez względu na wykorzystywany model promieniowania, niezwykle ważne jest poprawne opisanie współczynnika absorpcji światła dla dymu. W większości zastosowań inżynierskich za poprawną wartość tego współczynnika dla dymu przyjmuje się od 0,4 do 0,7 . Całkowita energia transportowana na drodze promieniowania powinna wynosić około $30 \%-40 \%$ energii powstałej w czasie pożaru, a jej wartość często opisuje się jako konwekcyjną moc pożaru.

\subsection{Ocena wyników obliczeń numerycznych}

Poprawne przedstawienie wyników analizy numerycznej jest równie trudne, jak poprawne przygotowanie 
założeń do analizy. Proces post-processingu to nie tylko generacja obrazów ilustrujących wyniki przeprowadzonych obliczeń, ale przede wszystkim ich analiza. Należy pamiętać, że zjawiska przebiegają w trzech wymiarach, podczas gdy obrazy je ilustrujące są zazwyczaj generowane na arbitralnie wybranych płaszczyznach. Ocena wyników bazująca jedynie na wynikach z wybranych obszarów może prowadzić do skrajnych ocen, niedoszacowania lub przeszacowania zagrożenia. Wątpliwości z doborem płaszczyzny wynikowej potęguje kwestia wielkości pojedynczego elementu siatki obliczeniowej, który może mieć nawet kilkanaście-kilkadziesiąt centymetrów. Osoba prowadząca obliczenia numeryczne musi posiadać wiedzę dotyczącą schematów uśredniania i przedstawiania wartości otrzymanych w czasie obliczeń numerycznych wewnątrz objętości kontrolnych.

Kryteria oceny wyników obliczeń numerycznych różnią się dla etapów ewakuacji osób z budynku oraz eta- pu prowadzenia działań ratowniczo gaśniczych. Wartości liczbowe kryteriów przedstawiono w tabeli 1. Więcej informacji dotyczących analizy wyników obliczeń numerycznych i stawianych kryteriów oceny analiz numerycznych można odnaleźć w publikacjach [25],[26],[27],[5862].

Ponieważ wyniki analizy obliczeń numerycznych odnoszą się do chwil czasowych związanych z procesem ewakuacji, nierozłącznym elementem każdej analizy numerycznej rozprzestrzeniania się dymu i ciepła jest ocena tzw. czasów ewakuacji, w tym najważniejszego - Wymaganego Czasu Bezpiecznej Ewakuacji (WCBE, ang. RSET). Analizy te mogą mieć charakter analityczny lub numeryczny, więcej informacji na ich temat można odnaleźć w publikacjach [62-65]. Wiedzę dotyczącą wykorzystania komputerowych modeli ewakuacji przedstawiono m.in. w publikacjach [62],[66-68].

Tabela 4.

Table 4.

Assessment criteria

\begin{tabular}{|c|c|c|c|}
\hline $\begin{array}{l}\text { Kryterium / } \\
\text { Criteria }\end{array}$ & $\begin{array}{l}\text { Wentylacja oddymiająca / } \\
\text { SHEVs }\end{array}$ & $\begin{array}{l}\text { Kontrola dymu i ciepła } \\
\text { Smoke control }\end{array}$ & $\begin{array}{l}\text { Oczyszczanie z dymu } \\
\text { Smoke clearence }\end{array}$ \\
\hline \multicolumn{4}{|c|}{ W czasie ewakuacji / during evacuation } \\
\hline $\begin{array}{l}\text { Temperatura / } \\
\text { Temperature }\end{array}$ & \multicolumn{3}{|c|}{$\begin{array}{l}\text { pod stropem / under the ceiling }-200^{\circ} \mathrm{C} \\
\text { na wysokości do } 1,80 \mathrm{~m} / \text { at the height of } 1,80 \mathrm{~m}-60^{\circ} \mathrm{C}\end{array}$} \\
\hline $\begin{array}{l}\text { Zadymienie / } \\
\text { Visibility }\end{array}$ & \multicolumn{3}{|c|}{$\begin{array}{l}\text { dym utrzymujący się pod stropem kondygnacji, } \\
\text { na wysokości do } 1,80 \mathrm{~m} / \mathrm{smoke} \text { in a layer under ceiling, at the height of } 1,80 \mathrm{~m} \text { mass density } \\
\text { of smoke not higher than }-0,105 \mathrm{~g} / \mathrm{m}^{3} \text { (zasięg widzialności znaków ewakuacyjnych świecących } \\
\text { własnym światłem }-10 \mathrm{~m} / \text { visibility of light emitting evacuation signs higher than } 10 \mathrm{~m} \text { ) }\end{array}$} \\
\hline $\begin{array}{l}\text { Promieniowanie } \\
\text { / Radiation } \\
\end{array}$ & \multicolumn{3}{|c|}{ mniej niż $2,5 \mathrm{~kW} / \mathrm{m}^{2} \mathrm{w}$ kierunku podłogi / radiation lower than $2,5 \mathrm{~kW} / \mathrm{m}^{2}$ towards the floor } \\
\hline \multicolumn{4}{|c|}{ W czasie prowadzenia działań ratowniczo gaśniczych / during the firefighting operation } \\
\hline $\begin{array}{l}\text { Temperatura / } \\
\text { Temperature } \\
\end{array}$ & \multicolumn{3}{|c|}{$\begin{array}{l}\text { na wysokości } 1,50 \mathrm{~m} \text { mniej niż } 120^{\circ} \mathrm{C} \text { w odległości ponad } 15 \mathrm{~m} \text { od źródła pożaru / at the height of } \\
1,50 \mathrm{~m} \text { less than } 120^{\circ} \mathrm{C} \text { in more than } 15 \text { away from the fire }\end{array}$} \\
\hline $\begin{array}{l}\text { Zadymienie / } \\
\text { Visibility }\end{array}$ & $\begin{array}{l}\text { Na wysokości } 1,50 \mathrm{~m} \text { do } 0,105 \\
\mathrm{~g} / \mathrm{m}^{3} \text { (zasięg widzialności } \\
\text { znaków ewakuacyjnych } \\
\text { świecących własnym światłem } \\
-10 \mathrm{~m} \text { ) w odległości do } 15 \mathrm{~m} \\
\text { od źródła pożaru / } \\
\text { At the height of } 1,50 \mathrm{~m} \text { up to } \\
0,105 \mathrm{~g} / \mathrm{m}^{3} \text { (visibility higher } \\
\text { than } 10 \mathrm{~m} \text { for light emitting } \\
\text { signs) further than } 15 \mathrm{~m} \text { away } \\
\text { from the fire }\end{array}$ & $\begin{array}{l}\text { Na wysokości } 1,50 \mathrm{~m} \text { do } 0,105 \\
\mathrm{~g} / \mathrm{m}^{3} \text { (zasięg widzialności } \\
\text { znaków ewakuacyjnych } \\
\text { świecących własnym światłem } \\
-10 \mathrm{~m} \text { ) } \mathrm{w} \text { odległości do } 15 \mathrm{~m} \\
\text { od źródła pożaru / At the height } \\
\text { of } 1,50 \mathrm{~m} \text { up to } 0,105 \mathrm{~g} / \mathrm{m}^{3} \\
\text { (visibility higher than } 10 \mathrm{~m} \text { for } \\
\text { light emitting signs) further } \\
\text { than } 15 \mathrm{~m} \text { away from the fire }\end{array}$ & $\begin{array}{l}\text { Strefa może być zadymiona / } \\
\text { Smoke zone can be filled with } \\
\text { smoke }\end{array}$ \\
\hline $\begin{array}{l}\text { Promieniowanie } \\
\text { / Radiation }\end{array}$ & \multicolumn{3}{|c|}{$\begin{array}{l}\text { Do } 15 \mathrm{~kW} / \mathrm{m}^{2} \mathrm{w} \text { odległości } 5 \mathrm{~m} \text { od źródła pożaru, } 5 \mathrm{~kW} / \mathrm{m}^{2} \mathrm{w} \text { odległości } 15 \mathrm{~m} \text { od źródła pożaru, } \\
2,5 \mathrm{~kW} / \mathrm{m}^{2} \mathrm{~W} \text { pozostałym obszarze } \\
\text { Up to } 15 \mathrm{~kW} / \mathrm{m}^{2} \text { in } 5 \mathrm{~m} \text { away from fire, up to } 5 \mathrm{~kW} / \mathrm{m}^{2} \text { in } 15 \mathrm{~m} \text { away from fire } 2,5 \mathrm{~kW} / \mathrm{m}^{2} \text { further } \\
\text { away }\end{array}$} \\
\hline $\begin{array}{l}\text { Dostęp do źródła } \\
\text { ognia / Access for } \\
\text { firefighters }\end{array}$ & $\begin{array}{l}\text { Dym w dwóch warstwach - } \\
\text { źródło pożaru jest widoczne } \\
\text { a dostęp do niego ułatwiony / } \\
\text { smoke in two layers, source of } \\
\text { fire visible and access to it is } \\
\text { possible }\end{array}$ & $\begin{array}{l}\text { Możliwy dostęp do źródła } \\
\text { pożaru w odległości do } 15 \mathrm{~m} \text { od } \\
\text { jego lokalizacji, drogą wolną } \\
\text { od dymu / sufficiently free of } \\
\text { smoke access to fire (15 m } \\
\text { away) }\end{array}$ & $\begin{array}{l}\text { Cały obszar strefy zadymiony } \\
\text { - strefa pożarowa powinna } \\
\text { być na tyle mała aby szybkie } \\
\text { odnalezienie i lokalizacja } \\
\text { pożaru były możliwe / } \\
\text { zone filled with smoke, } \\
\text { although its area should be } \\
\text { small enough that firefighting } \\
\text { operations will be possible }\end{array}$ \\
\hline
\end{tabular}

Źródło: Opracowanie własne.

Source: Own elaboration. 


\section{Odbiór systemów wentylacji pożarowej}

Skuteczny system wentylacji to nie tylko dobry projekt, ale także jego poprawne wykonanie, co oznacza pełną integrację systemu wentylacji pożarowej z innymi instalacjami bezpieczeństwa pożarowego $\mathrm{w}$ obiekcie. Takie współdziałanie może zostać zweryfikowane z wykorzystaniem prób $\mathrm{z}$ gorącym dymem. W trakcie prób imitujących rozwój rzeczywistego pożaru w budynku możliwa jest ocena przepływów powietrza wywołanych działaniem systemu w istniejącym obiekcie, lepsza regulacja bilansu powietrza nawiewanego poszczególnymi punktami nawiewnymi i przede wszystkim weryfikacja poprawności współpracy systemu wentylacji z systemem sygnalizacji pożaru wraz z oceną poprawności realizacji scenariusza pożarowego.

Standardy regulujące zakres odbiorów technicznych z uwagi na bezpieczeństwo pożarowe są przedmiotem prac wielu ośrodków na świecie. W Stanach Zjednoczonych organizacja NFPA opracowała wytyczne dotyczące procedur odbiorowych obiektów budowlanych [69]. Ponadto $w$ wytycznych tej organizacji [15] oraz [70] można znaleźć zalecenia dotyczące odbioru systemów wentylacji pożarowej. W kanadyjskim ośrodku CAN/ULC trwają prace nad standardem dot. zintegrowanego odbioru systemów bezpieczeństwa pożarowego oraz bezpieczeństwa życia [71]. Wytyczne prowadzenia testów odbiorowych systemów wentylacji pożarowej z wykorzystaniem źródeł ciepła zawarto w dokumentach australijskich [20],[72] a następnie przywołano w wytycznych singapurskich [21]. W Europie najbardziej zaawansowaną procedurę odbioru systemów wentylacji pożarowej zawarto $\mathrm{w}$ wytycznych niemieckich [18]. Obecnie trwają także zaawansowane prace nad jednolitym standardem dotyczącym projektowania, wykonawstwa oraz odbioru systemów wentylacji pożarowej garaży zamkniętych w ramach prac grupy roboczej CEN TC 191/SC1/WG9 [73].

$\mathrm{W}$ trakcie prac prowadzonych w ramach projektu rozwojowego NR 04000306 pt. ,Kontrola rozprzestrzeniania się dymu i ciepła w garażach" [1] przetestowano wiele rozwiązań generacji dymu, które mogłyby zostać wykorzystane do oceny skuteczności działania systemów bezpieczeństwa pożarowego. We wczesnej fazie projektu testowano różne typy świec dymowych i generatorów zimnego dymu. Ostatecznie opracowany zestaw urządzeń składa się z zestawu tac grzewczych z ciekłym paliwem, generatorów gorącego dymu odpornego na temperatury do $200^{\circ} \mathrm{C}$ oraz opcjonalnie urządzenia kontrolującego przebieg testu i integrującego wykorzystywane generatory dymu. Zaproponowana automatyzacja próby pozwoliła na całkowite uniezależnienie przebiegu testu od działań osób odpowiedzialnych za jego prowadzenie, co przedstawiono na ryc. 5 .

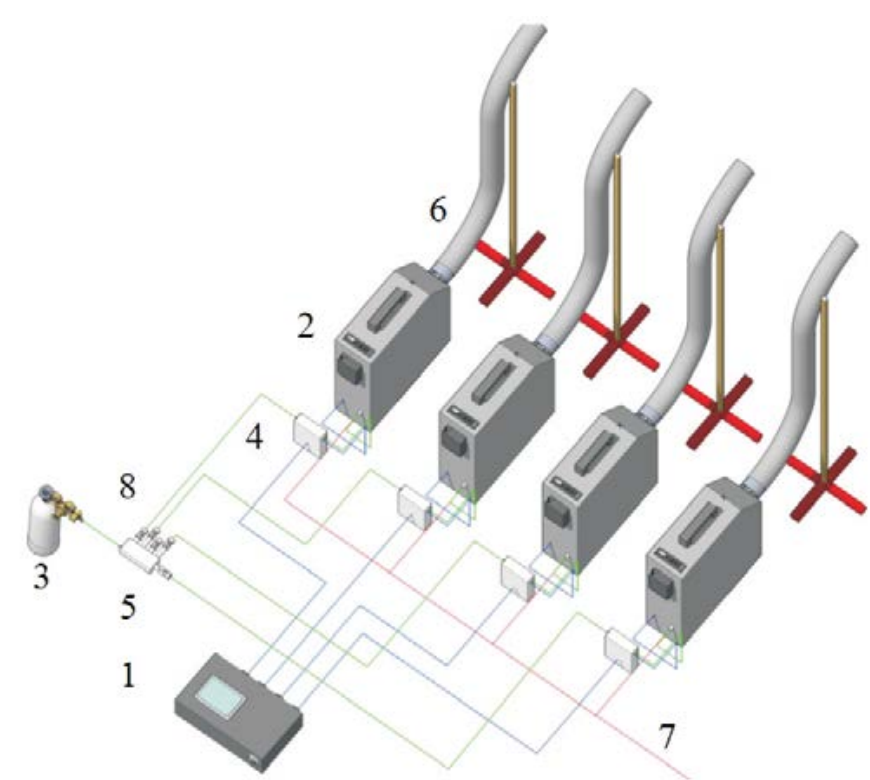

1 - urządzenie integrujące / integrating device; 2 - generatory dymu / smoke generators; 3 - butla z gazem roboczym / working gas; 4 - regulatory przepływu / flow regulators;

5 - kolektor / collector; 6 - zestaw przewodów elastycznych / wiring; 7 - źródło prądu (230 V AC) / source of electricity; 8 - zawór redukcyjny / reduction valve

Ryc. 5. Schemat zestawu integrującego generatory dymu Fig. 5. Scheme of smoke generators integrating device Źródło: Opracowanie własne.

Source: Own elaboration.

\subsection{Procedura prowadzenia testu $\mathrm{z}$ gorącym dymem}

Liczba tac z paliwem oraz liczba generatorów dymu dobierana jest indywidualnie dla każdego obiektu. Maksymalna moc pożaru testowego wykorzystywanego $\mathrm{w}$ trakcie testów z gorącym dymem wynosi do $1 \mathrm{MW}$. Do oszacowania mocy pożaru testowego można wykorzystać wytyczne przedstawione w [17] i [20]. Prowadzone przez nas badania eksperymentalne wykazały, iż moc pożaru generowana $\mathrm{z}$ jednej tacy $\mathrm{z}$ paliwem o wymiarach $0,50 \mathrm{~m}$ na $0,50 \mathrm{~m}$ zależy przede wszystkim od ilości użytego paliwa i zmienia się w przedziale od $100 \mathrm{~kW}$ do $170 \mathrm{~kW}$. Maksymalny czas spalania paliwa $\mathrm{w}$ pojedynczej tacy wynosi około 17 minut.

Przed przystąieniem do testu z wykorzystaniem gorącego dymu analizowana jest dokumentacja powykonawcza systemów bezpieczeństwa pożarowego w budynku, ze szczególnym uwzględnieniem systemów wentylacji pożarowej. Najistotniejszym dokumentem opisującym zachowanie systemów automatyki pożarowej w budynku jest scenariusz pożarowy, a w trakcie próby weryfikowana jest poprawność realizacji jego założeń.

Bezpośrednio przed rozpoczęciem testu z wykorzystaniem gorącego dymu uruchamiana jest instalacja wentylacji bytowej do momentu ustabilizowania się przepływów powietrza w badanej strefie. Rozpoczęcie testu następuje w momencie zapłonu pierwszej tacy z ciekłym paliwem oraz uruchomienia pierwszego generatora dymu. Zgodnie ze scenariuszem prowadzenia testu dla danego obiektu w określonych odstępach czasu następuje zapłon kolejnych tac z paliwem oraz uruchamianie pozostałych 
generatorów dymu. Mierzony jest czas od rozpoczęcia próby do detekcji pożaru przez system sygnalizacji pożaru w obiekcie.

System sygnalizacji pożarowej powinien automatycznie realizować zadania opisane w scenariuszu pożarowym dla danej strefy. Mierzone są czasy, w których nastąpiło osiagnięcie przez system wentylacji pożarowej zakładanej wydajności wyciągu oraz nawiewu powietrza kompensacyjnego, a także uruchomienie pozostałych elementów systemu. W przypadku systemów wentylacji pożarowej z wentylatorami strumieniowymi mierzone są czasy zwłoki od ogłoszenia alarmu pożarowego w badanej strefie pożarowej do momentu uruchomienia się wentylatorów strumieniowych. Czas trwania pojedynczej próby wynosi średnio od 12 do 20 minut [74].

W trakcie testów obserwuje się działanie wszystkich elementów automatyki pożarowej w budynku, takich jak bramy pożarowe, automatyczne kurtyny dymowe, przeciwpożarowe klapy odcinające, dźwiękowy system ostrzegawczy czy oświetlenie awaryjne i ewakuacyjne. Ponadto prowadzone są obserwacje przepływu dymu w budynku, formowanie się dwóch warstw dymu czy wydzielenie przestrzeni niezadymionych w budynku. Często podczas próby uruchamiany jest przeciwpożarowy wyłącznik prądu w budynku bądź ręczne ostrzegacze pożarowe w sąsiednich do badanej strefach pożarowych.

Zaproponowana metoda może być wykorzystana w celu oceny skuteczności działania systemów bezpieczeństwa pożarowego każdego rodzaju obiektów budowlanych. Metoda jest całkowicie niebrudząca oraz nie powoduje uszkodzeń konstrukcji czy elementów wykończenia wnętrz, w związku z czym nakłady finansowe niezbędne do przeprowadzenia tego typu testów są niewielkie.

\section{Porównanie wyników analiz numerycznych i prób z gorącym dymem}

Analizy numeryczne z wykorzystaniem metody CFD oraz testy $\mathrm{z}$ gorącym dymem są narzędziami inżynierskimi pozwalającymi ocenić skuteczność funkcjonowania systemów wentylacji pożarowej na różnych etapach powstawania obiektów budowlanych od momentu ich koncepcji aż po etap ich wykonania w rzeczywistości. Pomimo jednoznacznych różnic pomiędzy metodami, W szczególności w doborze wielkości pożaru testowego, jakościowa ocena systemu w obydwu metodach powinna być zbieżna. Elementy takie jak wydzielenie obszarów zadymionych (strefy dymowe) czy wpływ napływającego powietrza kompensacyjnego na mieszanie się warstwy dymu powinny mieć podobny przebieg w czasie prób z wykorzystaniem obydwu metod. To samo dotyczy wykonywanych pomiarów prędkości przepływu powietrza na zimno czy wyznaczenie przepływów w przestrzeni, z wyłączeniem miejsca w pobliżu źródła ognia powinny być do siebie zbliżone.

W celu zweryfikowania postawionej tezy przeprowadzono analizę porównawczą obliczeń numerycznych z wykorzystaniem metody CFD z testami systemów wentylacji pożarowej. Badania przeprowadzono $\mathrm{z}$ wykorzystaniem zestawu do przeprowadzania testów z gorą- cym dymem dla czterech wytypowanych obiektów, o powierzchni od $1250 \mathrm{~m}^{2}$ do $26650 \mathrm{~m}^{2}$. Dodatkowo wykonano także analizę porównawczą rozkładu prędkości przepływu powietrza $\mathrm{w}$ osi wentylatora strumieniowego $\mathrm{w}$ oparciu o badania eksperymentalne przeprowadzone przez ośrodek TNO z Holandii [75] i Uniwersytet w Eindhoven [76] oraz obliczenia numeryczne wykonane w oprogramowaniu ANSYS Fluent oraz FDS.

Przeprowadzone badania potwierdziły, że jakościowa ocena systemów wentylacji pożarowej z wykorzystaniem obydwu przedstawionych $\mathrm{w}$ artykule metod była podobna. Zaobserwowane w symulacjach zjawiska cofania się dymu czy mieszania dymu z napływającym powietrzem kompensacyjnym występowały w tych samych obszarach budynku, przy czym skala zjawiska w obydwu metodach była różna. Istotne różnice pomiędzy metodami występowały przy określaniu wysokości warstwy dymu czy prędkości przepływu dymu pod stropem, co może mieć związek z istotnymi różnicami w wielkości źródła pożaru - celowo ograniczanego w trakcie próby z gorącym dymem. Analiza porównawcza wyników badań prędkości przepływu powietrza wyrzucanego przez wentylator strumieniowy potwierdziła, że analizy numeryczne prowadzone w oprogramowaniu ANSYS Fluent $\mathrm{z}$ wykorzystaniem modeli przepływu turbulentnego $\mathrm{k}-\varepsilon$ znajdują zastosowanie $\mathrm{w}$ rozwiązywaniu zagadnień tego rodzaju.
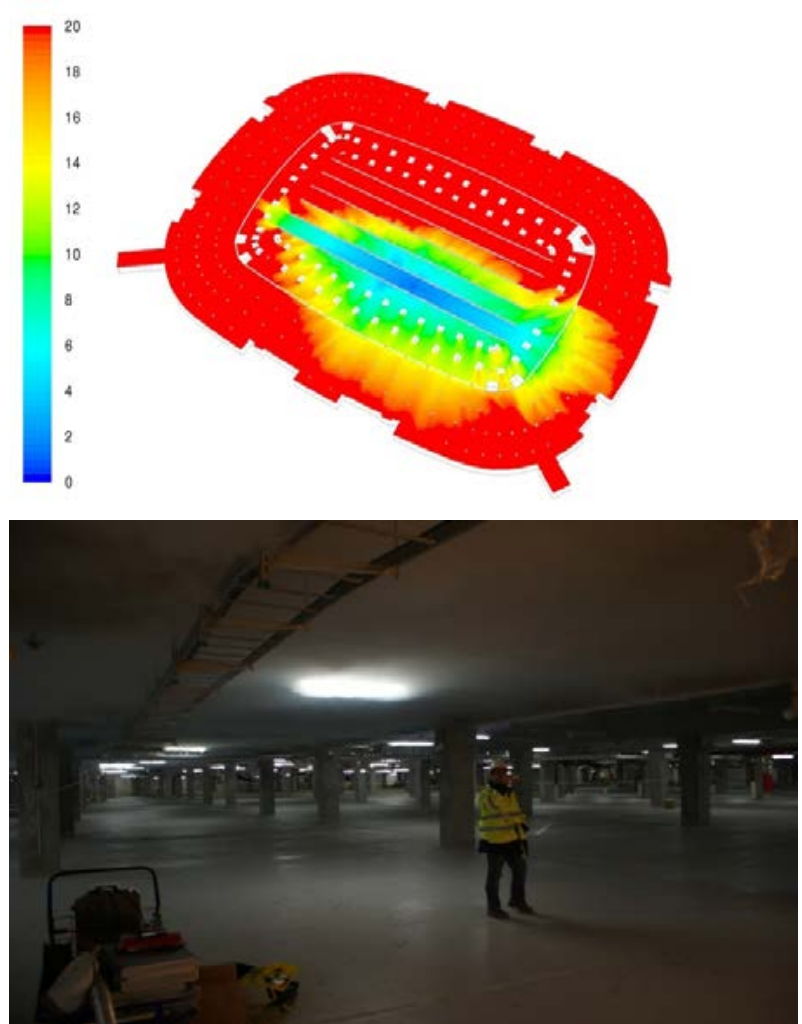

Ryc. 7. Dym płynący w kierunku przeciwnym do wymuszonego działaniem szachtów przepływu powietrza, pomiędzy dwoma podciągami w obiekcie, zaobserwowany w obliczeniach numerycznych i podczas prób z gorącym dymem [1]

Fig. 7. View of a smoke flowing against the forced ventilation direction between two beams underneath the ceiling in CFD and in hot smoke tests [1] 

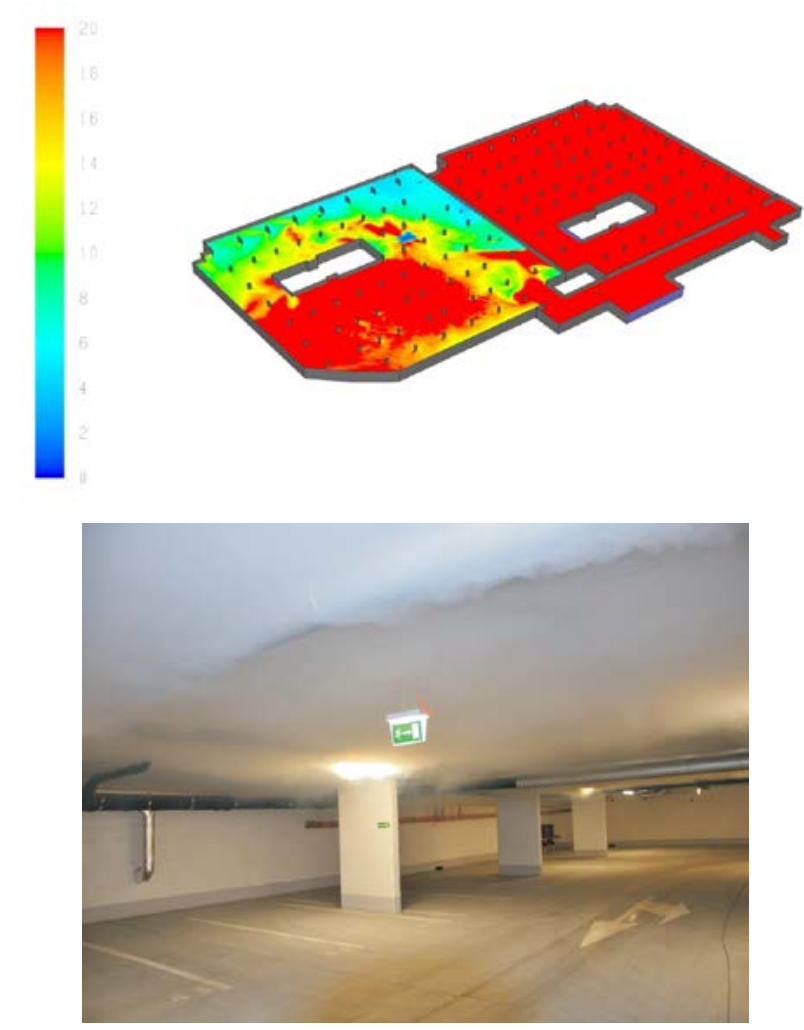

Ryc. 8. Opadanie dymu w pobliżu ściany budynku zaobserwowane w obliczeniach numerycznych oraz podczas prób z gorącym dymem [1]

Fig. 8. Smoke falling observed in CFD calculations and hot smoke tests [1]

\section{Podsumowanie}

W pracy przedstawiono przegląd wiedzy oraz doświadczeń naukowych autorów opracowania w istotnych aspektach wykorzystania nowoczesnych narzędzi inżynierskich w projektowaniu i odbiorze systemów wentylacji pożarowej garaży zamkniętych. Liczymy, że korzy- stając z przytoczonych źródeł, osoby, które chcą zgłębiać swoją wiedzę w omawianym zakresie, będą w stanie znaleźć odpowiedź na nurtujące je pytania. Znajomość źródeł wiedzy jest w dziedzinie, którą omawiano, szczególnie ważna, ponieważ rzetelny dowód skuteczności zaprojektowanego systemu wentylacji pożarowej jest dziś formalnym wymogiem przepisów prawa ( $\$ 270$ rozporządzenia [6]). Oczywiście dowód ten może przybrać formę opinii technicznej bądź ekspertyzy popartej np. analizą numeryczną rozprzestrzeniania się dymu i ciepła. W tym wypadku, oprócz przedstawienia wyników analizy i oceny własnej autora, niezbędne jest podanie szczegółowego opisu rozwiązywanych zależności (wybranych modeli i sub-modeli fizycznych), założeń dotyczących źródła pożaru i spalanego materiału czy kryteriów oceny wyników analizy. W obecnej chwili brakuje krajowych uregulowań w omawianym zakresie. Próbę wypełnienia tej luki podjęli autorzy opracowania w przygotowywanym do opublikowania dokumencie [22] i dostępnych już publikacjach [23],[24]. Ciekawe spostrzeżenia związane z wykorzystaniem metod numerycznych w inżynierii bezpieczeństwa pożarowego zawarto w publikacjach [25],[26], a interesującą próbę określenia wymagań stawianych oprogramowaniu podjęli autorzy opracowania [77].

W przypadku, gdy ocena skuteczności funkcjonowania musi być przeprowadzona dla istniejącego obiektu, alternatywą dla analiz numerycznych są próby z gorącym dymem. Przewagą tego typu działania jest przede wszystkim możliwość oceny współpracy badanego systemu z pozostałymi elementami automatyki pożarowej nierozłącznie powiązanymi z wentylacją pożarową. Ocena ilościowa systemu podczas próby z gorącym dymem jest niezwykle trudna (o ile w ogóle możliwa), jednak wnioski jakościowe płynące z obserwacji i pomiarów prowadzonych w czasie próby mogą być wystarczające do jednoznacznej oceny przydatności badanej instalacji na wypadek prawdziwego pożaru. Podobnie jak w przypadku ana-
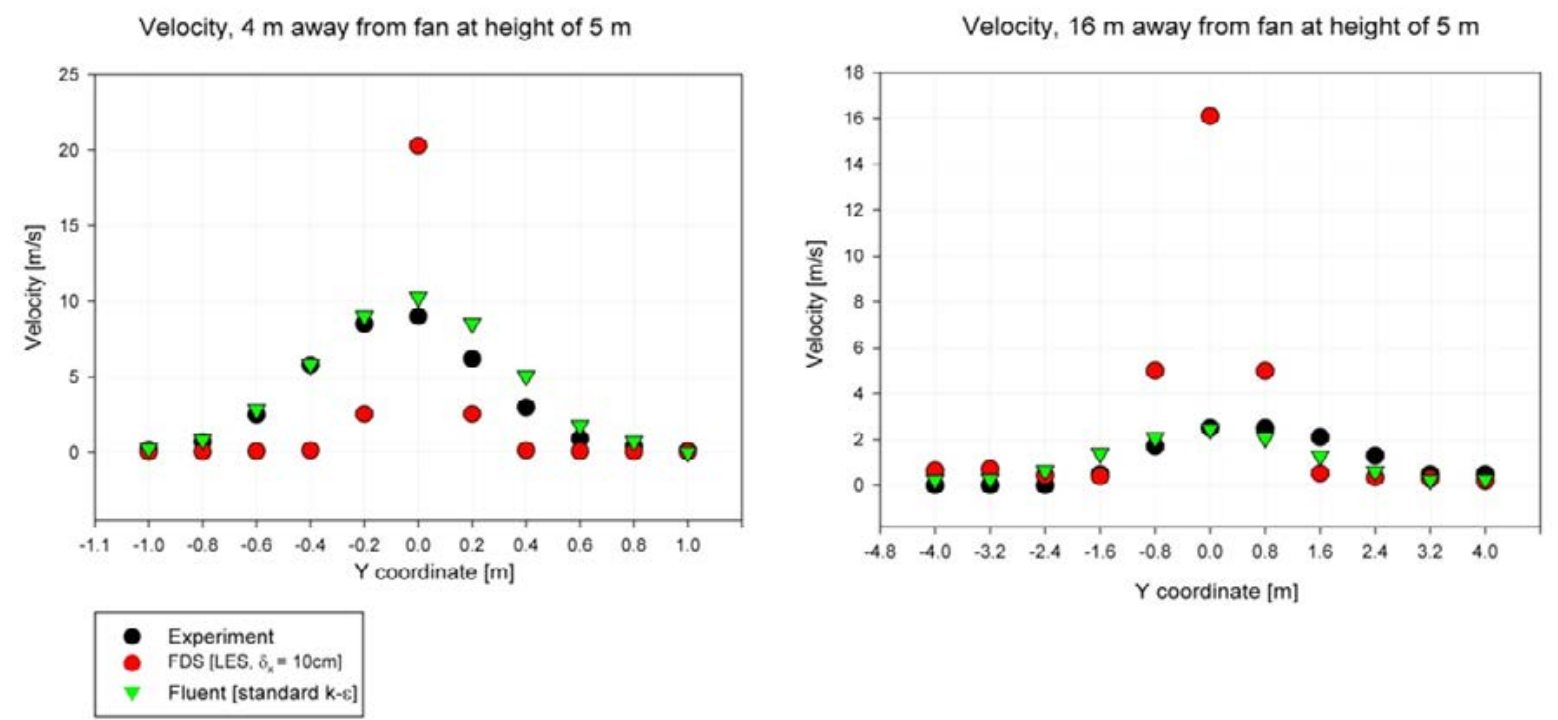

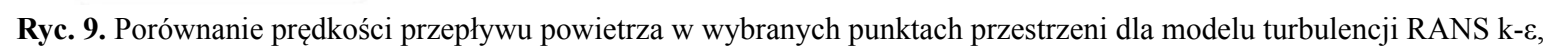
LES oraz badań eksperymentalnych [1]

Fig. 9. Comparison of air velocity in chosen points of space for turbulence models RANS k k-e, LES and obtained from experiment [1] 
liz numerycznych brakuje jednoznacznych wytycznych opisujących w wyczerpujący sposób procedurę i wymagania stawiane próbom z gorącym dymem. Najlepszymi dostępnymi źródłami wiedzy w tym zakresie są normy [18] i [20] oraz publikacje podsumowujące bogate doświadczenia Zakładu Badań Ogniowych Instytutu Techniki Budowlanej w prowadzeniu tego typu prób [2],[74]. Próba usystematyzowania zagadnień związanych $\mathrm{z}$ odbiorem instalacji wentylacji pożarowej, w tym także z wykorzystaniem metody gorącego dymu, będzie podjęta w zapowiedzianej wcześniej publikacji [22].

\section{Wnioski}

Wykorzystanie nowoczesnych narzędzi inżynierii bezpieczeństwa pożarowego, jakimi są analizy z wykorzystaniem metody obliczeniowej mechaniki płynów (CFD) oraz metoda gorącego dymu jest dzisiaj powszechną procedurą towarzyszącą niemalże każdemu projektowi systemu wentylacji pożarowej garażu zamkniętego. Przedstawiane wyniki analiz są często trudne w interpretacji i niejednoznaczne. Osoby prowadzące weryfikację tych projektów, funkcjonariusze PSP odpowiadający za odbiór i inne podmioty biorące udział $\mathrm{w}$ procesie projektowania muszą mieć świadomość źródła pochodzenia przyjętych założeń i uproszczeń oraz być w stanie zweryfikować podstawy ich zastosowania. Dopiero takie w pełni świadome wykorzystanie narzędzi, którymi dysponujemy, daje pewność, że wyniki analiz są bliskie rzeczywistości, a wnioski z nich płynące poprawne.

\section{Literatura}

1. Sztarbała G. (kier. projektu), projekt rozwojowy pt. „Kontrola rozprzestrzeniania się dymu i ciepła w garażach" NR 040003 06, Warszawa 2009-2012.

2. Sztarbała G., Węgrzyński W., Krajewski G., Wykorzystanie metody goracego dymu do oceny skuteczności funkcjonowania systemów bezpieczeństwa pożarowego w obiektach budowlanych, Konferencja Bezpieczeństwo Pożarowe Obiektów Budowlanych, Warszawa, 2012.

3. Węgrzyński W., Krajewski G., Wykorzystanie badań w skali modelowej do weryfikacji obliczeń CFD wentylacji pożarowej w tunelach komunikacyjnych, Konferencja BiBT, Kraków 2014.

4. Węgrzyński W., Przepływ dymu i ciepła w wielkokubaturowym obiekcie budowlanym $w$ warunkach pożaru, „Budownictwo i Architektura", Vol. 12 Issue 2, 2013, pp. 165-172.

5. Węgrzyński W., Krajewski G., Wentylacja strumieniowa, „Przegląd Pożarniczy”, Issue 4, 2014.

6. Rozporządzenie Ministra Infrastruktury w sprawie warunków technicznych, jakim powinny odpowiadać budynki i ich usytuowanie z dnia 12 kwietnia 2002 r. (Dz. U. nr 75, poz. 690) z późniejszymi zmianami.

7. Węgrzyński W., Krajewski G., Doświadczenia z wykorzystania narzędzi inżynierskich do oceny skuteczności funkcjonowania systemów wentylacji oddymiającej, „Materiały budowlane", Issue 7, 2014, pp. 26-29.

8. Węgrzyński W., Krajewski G., Sulik P., Systemy wentylacji pożarowej w budynkach, ,Inżynier Budownictwa”, Issue 9, 2014, pp. 54-59.

9. Krajewski G., Węgrzyński W., Głąbski P., Projektowanie systemów wentylacji pożarowej w obiektach budowlanych.
Kurs organizowany przez Zakład Badań Ogniowych. Warszawa, Instytut Techniki Budowlanej, 2014.

10. Węgrzyński W., Sztarbała G., Krajewski G., Praktyczne aspekty zastosowania wentylacji strumieniowej $w$ garażach zamkniętych, „Budownictwo Górnicze i Tunelowe”, Issue 3, 2012, pp. 6-10.

11. Sztarbała G., Węgrzyński W., Krajewski G., Kontrola rozprzestrzeniania się dymu i ciepla $w$ garażach, „Materiały Budowlane", Issue 7, 2012, pp. 50-52.

12. Sulik P., Węgrzyński W., Podziat przestrzeni w budynku a rozprzestrzenianie się pożaru, „Inżynier Budownictwa”, Issue 5, 2014.

13. BS 7346-7:2006 Components for smoke and heat control systems - Part 7: Code of practice on functional recommendations and calculation methods for smoke and heat control systems for covered car parks, BSI, 2006

14. NFPA 92:2012 - Standard for Smoke Control Systems, National Fire Protection Association, 2012.

15. NFPA 204:2012 - Standard for Smoke and Heat Venting, National Fire Protection Association, 2012.

16. NEN 6098:2010 Rookbeheersingssystemen voor mechanisch geventileerde parkeergarages.

17. NBN S 21-208-2 Brandbeveiligin g in gebouwen - Ontwerp van rook- en warmteafvoersystemen (RWA) van gesloten parkeergebouwen .

18. VDI 6019 Blatt 1 Ingenieurverfahren zur Bemessung der Rauchableitung aus Gebäuden Brandverläufe, Überprüfung der Wirksamkeit, 2006.

19. VDI 6019 Blatt 2 Ingenieurverfahren zur Bemessungder Rauchableitung aus Gebäuden Ingenieurmethoden, 2009.

20. AS 4391 - 1999 Smoke management systems - Hot smoke test.

21. FSE3:2008 Fire safety requirements for ductless jet fan system in car parks, 2008.

22. Węgrzyński W., Krajewski G., Wytyczne projektowania, weryfikacji i odbioru systemów wentylacji pożarowej, Instytut Techniki Budowlanej, 2014.

23. Krajewski G., Węgrzyński W., Wentylacja pożarowa garaży - błędy projektowe $i$ wykonawcze, „Materiały Budowlane”, Issue 10, 2014, pp. 141-143.

24. Węgrzyński W., Krajewski G., Dobór modeli oraz warunków brzegowych a wynik analizy numerycznej rozprzestrzeniania się dymu i ciepta, „Materiały Budowlane”, Issue 10, 2014, pp. 144-146.

25. McGrattan K., Miles S., Modelling Enclosure Fires Using Computational Fluid Dynam-ics (CFD), [w:] SFPE Handbook of Fire Protection Engineering, 3rd Edition, Massachusetts, NFPA, 2008, s. 3-229 - 3-246.

26. Rudniak L., Sztarbała G., Krajewski G., Zastosowanie obliczeniowej mechaniki plynów [CFD] do prognozowania rozprzestrzeniania dymu i transportu ciepta $w$ obiektach budowlanych, Inż. Ap. Chem. 2010, 49, 4, 66-67.

27. Sztarbała G., An estimation of conditions inside construction works during a fire with the use of Computational Fluid Dynamics, "Bulletin of the Polish Academy of Sciences. Technical Sciences", Vol. 61 Issue 1, 2013.

28. Karlsson B., Quintiere J., Enclosure Fire Dynamics, CRC Press, 2000.

29. Hadijsophocleous G., McCartney C., Guidelines for the Use of CFD Simulations for Fire and Smoke Modeling, "ASHRAE Transactions", Vol. 111 Issue 2, 2005.

30. Flaga A., Błazik-Borowa E. i Podgórski J., Aerodynamika smuktych budowli i konstrukcji prętowo-ciegnowych, Wydawnictwo Politechniki Lubelskiej, Lublin, 2004. 
31. Patankar S.V., Numerical heat transfer and fluid flow, McGraw-Hill Book Company, 1980.

32. Gryboś R., Podstawy mechaniki plynów, PWN, Warszawa 1998.

33. Ferziger J. H., Perić M., Computational methods for fluid dynamics, Springer, 2002

34. Chung T. J., Computational fluid dynamics, Cambridge University Press, 2002.

35. Kazimierski Z., Podstawy mechaniki plynów i metod komputerowej symulacji przeplywów, Wydawnictwo Politechniki Łódzkiej, Łódź 2004.

36. Błazik-Borowa E., Problemy zwiazane ze stosowanie modelu tubulencji k-e do wyznaczania parametrów optywu budynków, Wydawnictwo Politechniki Lubelskiej, Lublin 2008.

37. Launder B.E., Sharma B.I., Mathematical Models of Turbulence, Academic Press, 1972.

38. Launder B.E., Sharma B.I., The Numerical Computation of Turbulence Flow, "Computer Methods in Applied Mechanics and Engineering", Issue 3, 1974, pp. 269-289.

39. Wilcox D.C., Turbulence Modeling for CFD, 3 rd. edition, DCW Industries Inc., 2006.

40. Pope S.B., Ten questions concerning the large-eddy simulation of turbulent flows, "New Journal of Physics", Issue 6, 2004.

41. McGrattan K. i inni, Fire Dynamics Simulator User's Guide, NIST Special Publication 1019, Sixth Edition, 2014.

42. Jannsens M., Development of a database of full-scale calorimeter tests of motor vehicle burns, Southwest Research Institute, San Antonio, Texas 2008.

43. Mangs J., Keski-Rahkonen O., Characterization of the Fire Behavior of a Burning Passanger Car. Part I: Car Fire Experiments, „Fire Safety Journal”, Vol. 23, 1994.

44. Shipp M., Spearpoint M., Measurments of the severity of $f$ res involving private motor vechivles, "Fire and Materials", Vol. 19, 1995.

45. Joyeux D, Natural Fires in Closed Car Parks - Car Fire Tests, CTICM Report No. INC 96/294d DJ/NB, CTICM, Metz, 1997.

46. Steinert C., Experimental Investigation of Burning and Fire Jumping Behavior of Automobiles, VFDB, Vol. 49, 2000.

47. Stroup D. i inni, Passenger Minivan Fire Tests FR 4011, National Institute of Standards and Technology, Gaithersburg 2001.

48. Van Oerle N., Lemaire A., van de Leur P., Effectiveness of Forced Ventilation in Closed Car Parks, TNO Report No. 1999-CVB-RR1442, TNO, Delft 1999.

49. Santrock J., Evaluation of Motor Vehicle Fire Initiation and Propagation, Part 3: Propagation in an Engine Compartment Fire in a 1996 Passenger Van, NHTSA 1998 3588119, General Motors Corporation, 2001.

50. CTICM Fire Tests on Cars, CTICM, Metz 2004.

51. Shintani Y. i inni, Experimental Investigation of Burning Behavior of Automobiles, 6th Asia-Oceania Symposium on Fire Science and Technology, Daegu, 2004, s. 618-629.

52. Fire Spread in Car Parks, BRE, Londyn 2010.

53. Persson B., Simonson M., Fire emissions into the atmosphere, "Fire Technology", Vol. 34 Issue 3, 1998, pp. 266279.

54. Jekel L., Tam E. K. L., Environmental Sustainability: Plastic's Evolving Role in the Automotive Life Cycle, CSCE/ EWRI of ASCE Environmental Engineering Conference, Niagara 2002.

55. Lonnermark A., Blomqvist P., Emissions from an automobile fire, Chemosphere, Vol. 62, 2006, pp. 1043-1056.
56. Harper C.A., Handbook of Building Materials For Fire Protection, McGraw-Hill Book Company, Lutherville 2004.

57. ANSYS Fluent 13.0.0. Technical documentation.

58. Weng Poh., Tenability criteria for design of smoke hazard management systems, "Ecolibrium", Issue 8, 2011, pp. 32-37.

59. Weng Poh., Tenability in Building Fires: Limits and Design, "Fire Australia", Tom Spring 2010.

60. Purser David A., Toxicity assessment of combustion products, SFPE Handbook of Fire Protection Engineering, 3rd Edition, NFPA \& SFPE, 2002, s. 2/83-2/171.

61. Narodowe Centrum Badań Jądrowych, Poradnik metod ocen ryzyka zwiazanego z niebezpiecznymi instalacjami procesowymi [dok. elektr.] http://manhaz.cyf.gov.pl/manhaz/ przewodnik/default.htm [dostęp 15 kwiecień 2014].

62. PD 7974-6:2004 The application of fire safety engineering principles to fire safety design of buildings - Part 6: Human factors: Life safety strategies - Occupant evacuation, behaviors and condition (Sub-system 6), BSI, 2004

63. CFPA-E No 19:2009 Fire safety engineering concerning evacuation from buildings, CFPA Europe, 2009.

64. Nelson Harold E., Mowrer Frederick W., Emergency movement, SFPE Handbook of Fire Protection Engineering, Third Edition, ,NFPA \& SFPE, 2002, s. 3-367 - 3-380.

65. Proulx G., Movement of People: The Evacuation Timing, SFPE Handbook of Fire Protection Engineering, Third Edition, NFPA \& SFPE, 2002. s. 3/342-3/366.

66. Węgrzyński W., Komputerowa symulacja ewakuacji ludzi z budynków wysokich, Konferencja Ochrony Mienia i Informacji, Warszawa 2013.

67. Kuligowski Erica D., Peacock Richard D., A Review of Building Evacuation Models, NIST TN - 1471, Washington 2005.

68. Kuligowski Erica D., Peacock Richard D., Hoskins Bryan L., A Review of Building Evacuation Models, 2nd Edition, NIST TN - 1680, Washington 2010.

69. NFPA 3: Recomended Practice on Commissioning and Integrated Testing of Fire Protection and Life, Safety Systems. 2012

70. NFPA 130: Standard for Fixed Guideway Transit and Passenger Rail Systems, 2010

71. CAN/ULC-S1001 First Draft, Proposed First Edition July 2011, Integrated Systems Testing of Fire Protection and Life Safety Systems, 2011.

72. AS 2665-2001: Smoke/heat venting systems -Design, installation and commissioning

73. prEN/TS 12101:11, Smoke and Heat Control System - Part 11: Design, Installation \& Commissioning Requirements for Enclosed Car Parks, Draft Version, 2011.

74. Sztarbała G., Węgrzyński W., Krajewski G., Zastosowanie goracego dymu do oceny skuteczności działania systemów bezpieczeństwa pożarowego podziemnych obiektów, Materiały konferencyjne Budownictwo Podziemne i Bezpieczeństwo w Komunikacji Drogowej i Infrastrukturze Miejskiej, Kraków 2012.

75. N.J. van Oerle A.D. LEmaire, P.H.E. v.d. Leur. The effectivness of thrust ventiulation in closed car parks - Fire tests and simulation, Report 1999-CVB-R1442/OEN/LRP, TNO, Delft 1999.

76. B.J.M. v.d. Giesen S.H.A. Penders, M.G.L.C. Loomans, P.G.S. rutten, J.L.M. Hensen, Modelling and simulation of a jet fan for controlled air flowe in large enclosures.. 2011, "Environmental Modelling \& Software", Vol. 26 Issue 2, 2011, pp. 191-200. 
77. Fliszkiewicz M., Krauze A., Maciak T., Możliwości stosowania programów komputerowych w inżynierii bezpieczeństwa pożarowego, BiTP, Vol. 29 Issue 1, 2013, pp. 47-60.

mgr inż. Wojciech Węgrzyński - absolwent Wydziału Inżynierii Bezpieczeństwa Pożarowego Szkoły Głównej Służby Pożarniczej, doktorant w Instytucie Techniki Budowlanej. Od 2010 roku zatrudniony w Zakładzie Badań Ogniowych Instytutu Techniki Budowlanej. Obecnie pełni funkcję Kierownika Pracowni Kontroli Dymu, Sygnalizacji i Automatyki Pożarowej. Obszarem zainteresowań naukowych autora są zjawiska związane z przepływem dymu i wentylacją pożarową, rozwojem pożaru oraz narzędzia inżynierskie wykorzystywane w ich analizie. mgr inż. Grzegorz Krajewski - pracownik Zakładu Badań Ogniowych Instytutu Techniki budowlanej od 2007 r. Ukończył wydział Inżynierii Środowiska na Politechnice Warszawskiej. Specjalizuje się w zakresie analiz numerycznych z wykorzystaniem metody numerycznej mechaniki płynów (CFD), w szczególności w obszarze rozprzestrzeniania się dymu i ciepła oraz oddziaływania warunków środowiska zewnętrznego na obiekty budowlane (przepływy wewnętrzne, aerodynamika obiektów budowlanych). Współautor opracowań z projektów badawczo-rozwojowych oraz szeregu artykułów i publikacji naukowo-technicznych na konferencjach krajowych i zagranicznych o tematyce związanej z bezpieczeństwem pożarowym, inżynierią wiatrową oraz analizami numerycznymi. 